\title{
Multivariate benthic ecosystem functioning in the Arctic - benthic fluxes explained by environmental parameters in the southeastern Beaufort Sea
}

\author{
H. Link ${ }^{1}$, G. Chaillou ${ }^{2}$, A. Forest ${ }^{3}$, D. Piepenburg ${ }^{4}$, and P. Archambault ${ }^{1}$ \\ ${ }^{1}$ Institut des Sciences de la Mer, Université du Québec à Rimouski, G5L 3A1 Rimouski, Canada \\ ${ }^{2}$ Canada Research Chair in the Geochemistry of Coastal Hydrogeosystems, Department of Biology, Chemistry and \\ Geography, Université du Québec à Rimouski, G5L 3A1 Rimouski, Canada \\ ${ }^{3}$ Takuvik Joint International Laboratory, UMI3376, Université Laval (Canada) - CNRS (France), Département de Biologie \\ and Québec-Océan, Université Laval, Québec, G1V 0A6, Canada \\ ${ }^{4}$ Mainz Academy of Sciences, the Humanities and Literature, c/o Institute for Polar Ecology of the University of Kiel, \\ 24148 Kiel, Germany
}

Correspondence to: H. Link (link.heike@gmail.com) and G. Chaillou (gwenaelle_chaillou@uqar.ca)

Received: 1 October 2012 - Published in Biogeosciences Discuss.: 30 November 2012

Revised: 18 July 2013 - Accepted: 24 July 2013 - Published: 10 September 2013

\begin{abstract}
The effects of climate change on Arctic marine ecosystems and their biogeochemical cycles are difficult to predict given the complex physical, biological and chemical interactions among the ecosystem components. We studied benthic biogeochemical fluxes in the Arctic and the influence of short-term (seasonal to annual), long-term (annual to decadal) and other environmental variability on their spatial distribution to provide a baseline for estimates of the impact of future changes. In summer 2009, we measured fluxes of dissolved oxygen, nitrate, nitrite, ammonia, soluble reactive phosphate and silicic acid at the sediment-water interface at eight sites in the southeastern Beaufort Sea at water depths from 45 to $580 \mathrm{~m}$. The spatial pattern of the measured benthic boundary fluxes was heterogeneous. Multivariate analysis of flux data showed that no single or reduced combination of fluxes could explain the majority of spatial variation, indicating that oxygen flux is not representative of other nutrient sink-source dynamics. We tested the influence of eight environmental parameters on single benthic fluxes. Short-term environmental parameters (sinking flux of particulate organic carbon above the bottom, sediment surface $\mathrm{Chl} a$ ) were most important for explaining oxygen, ammonium and nitrate fluxes. Longterm parameters (porosity, surface manganese and iron concentration, bottom water oxygen concentrations) together
\end{abstract}

with $\delta^{13} \mathrm{C}_{\mathrm{org}}$ signature explained most of the spatial variation in phosphate, nitrate and nitrite fluxes. Variation in pigments at the sediment surface was most important to explain variation in fluxes of silicic acid. In a model including all fluxes synchronously, the overall spatial distribution could be best explained $(57 \%)$ by the combination of sediment Chl $a$, phaeopigments, $\delta^{13} \mathrm{C}_{\mathrm{org}}$, surficial manganese and bottom water oxygen concentration. We conclude that it is necessary to consider long-term environmental variability along with rapidly ongoing environmental changes to predict the flux of oxygen and nutrients across Arctic sediments even at short timescales. Our results contribute to improve ecological models predicting the impact of climate change on the functioning of marine ecosystems.

\section{Introduction}

Increased effort is put into estimating climate change effects in Arctic ecosystems (ACIA, 2004; Barber et al., 2012; Wassmann et al., 2011). Contrary to multilevel analyses of pelagic processes (Forest et al., 2011; Tremblay et al., 2011), few studies have tried to link environmental conditions to multilevel benthic ecosystem functioning in the Arctic (Schmid et al., 2009). Marine soft-bottom environments 
play a pivotal role in the remineralisation of the organic matter settling to the seafloor, what we define as the benthic remineralisation function. Sediments can be both a major source of nutrients and carbon to the overlying water column or/and a significant sink (Schulz, 2006). Typically, a significant fraction of exported organic matter undergoes biologically mediated degradation and oxidation through a complex web of redox reactions, while a small remaining fraction is permanently buried (Berner, 1980). Determining the spatial variation and partition between source fluxes from and sink fluxes to the sediments is important for improving our understanding of regional biogeochemical cycles (Ebenhöh et al., 1995; Zabel and Hensen, 2006) and, hence, the overall ecosystem functioning. Only few data are available from the Arctic regions, which are particularly sensitive to climate change (Chang and Devol, 2009; Darnis et al., 2012; Davenport et al., 2012; Rysgaard et al., 1998). Due to the more costly collection of nutrient flux data, oxygen uptake is often used as a proxy of total benthic ecosystem functioning, more precisely of activity and benthic remineralisation function (Glud, 2008; Hensen et al., 2006; Holstein and Hensen, 2010; Wenzhöfer and Glud, 2002). However, evidence is increasing that benthic nutrient remineralisation is not directly correlated with oxygen uptake, particularly in coastal and shelf environments (Braeckman et al., 2010; Davenport et al., 2012; Holstein and Hensen, 2010; Michaud et al., 2009; Robert et al., 2013). An evaluation of benthic remineralisation function and its relation with oxygen uptake in the Arctic is needed.

A wide range of environmental factors influence benthic processes. Determining their relative importance is difficult due to the number and complexity of biotic and abiotic interactions among the processes involved (Godbold and Solan, 2009). Organic carbon content in sediments has been proposed to be the principal driver of benthic remineralisation. Several different metabolic pathways contribute to the degradation of organic carbon, with oxygen, nitrate, manganese, iron and sulfate being the most important agents of remineralisation (Canfield et al., 1993; Froelich et al., 1979). Their relative importance varies temporally and spatially due to changes in environmental conditions. Thus, organic carbon content of sediments seems less predictive of benthic remineralisation (Rysgaard et al., 1998) than the quantity of fresh organic matter deposited on the seafloor (Chang and Devol, 2009; Link et al., 2011). Also, historical input of organic matter, ambient water oxygen concentration and porosity modifies the oxygen penetration of sediments and therefore its reactivity (Gobeil et al., 2001). Finally, biologically mediated degradation in Arctic marine sediments seems to be enhanced if labile, marine-derived matter is present (Sun et al., 2009). Thus, the quality of organic matter at the seafloor will influence the pattern of benthic remineralisation function (Rysgaard et al., 1998). More information, how environmental factors influence nitrate, phosphate or silicic acid fluxes will be useful for the prediction of single fluxes in the face of environmental change. Moreover, finding environmental parameters that could predict the overall pattern of multiple remineralisation fluxes will be valuable from the ecosystem perspective.

The continental shelf off the Mackenzie Delta in the Beaufort Sea may be particularly sensitive to climate change: among Arctic rivers, the Mackenzie is the largest exporter of particulate organic matter and ranks third in total terrigenous organic carbon input (dissolved and particulate) to the Arctic seas (Rachold et al., 2004). Over the last two decades, this region has experienced a significant reduction in summertime ice cover (Galley et al., 2008), an increase in ultraviolet radiation (Bélanger et al., 2006), as well as an earlier onset of primary production in spring (Tremblay et al., 2011). These changes would result in a greater export of terrigenous carbon to the Arctic Ocean (Benner et al., 2004) and shifts in marine produced vertical carbon export (Forest et al., 2011). Direct and indirect effects of these changes on Arctic Ocean biogeochemical cycles are difficult to predict in quantitative terms given the complexity of physical, biological and chemical interactions among ecosystem components. It is clear, however, that the flux of organic matter to coastal and shelf Arctic sediments will be considerably altered, which in turn will severely affect benthic ecosystem functioning, including the processes of nutrient remineralisation. Reducing the current lack of knowledge on benthic remineralisation function in Arctic regions, or on its link with environmental changes on different timescales, will help to evaluate biogeochemical budgets on larger timescales.

As part of the larger Malina programme (http://malina. obs-vlfr.fr/), which aims to predict Arctic ecosystem reactions to changes in light penetration of the ocean and climate, we want to fill gaps in benthic ecosystem process knowledge. The objective of this study was to determine what drives spatial variation in benthic remineralisation function measured as benthic boundary fluxes in the Beaufort Sea/Mackenzie Shelf. Emphasis is put on the ecological perspective and setting, and a hypothesis-driven approach, using multivariate statistics. We tackle our objective by addressing the following subjects: (1) ineffectiveness of oxygen flux as proxy for spatial patterns in benthic boundary fluxes; (2) timescales and distinct environmental forcings on different biogeochemical fluxes; and (3) statistical modelling of benthic remineralisation function using environmental parameters.

\section{Material and methods}

\subsection{Study region}

This study was conducted in the southeastern Beaufort Sea with emphasis on the shelf off the Mackenzie Delta (Fig. 1). The study area is dominated by coastal shelves and 
the maximum depth of our study was $580 \mathrm{~m}$ on the outer Mackenzie Shelf. Annual primary production ranges from 30 to $70 \mathrm{~g} \mathrm{C} \mathrm{m}^{-2} \mathrm{yr}^{-1}$, indicating generally oligotrophic conditions (Sakshaug, 2004). Rather low primary production daily rates $\left(73 \pm 37 \mathrm{mg} \mathrm{C} \mathrm{m}^{-2} \mathrm{~d}^{-1}\right)$ were also found in summer or fall 2005-2007 in the eastern Beaufort Sea (Ardyna et al., 2011). In the Cape Bathurst polynya at the eastern boundary of the study area, however, rates are apparently higher, reaching 90 to $175 \mathrm{~g} \mathrm{C} \mathrm{m}^{-2} \mathrm{yr}^{-1}$ as based on satellite estimates (Arrigo and van Dijken, 2004). Ardyna et al. (2011) reported daily primary production rates of $159 \pm 123 \mathrm{mg} \mathrm{C} \mathrm{m}^{-2} \mathrm{~d}^{-1}$ in summer and fall, and intensive phytoplankton blooms related to ice-edge upwelling events were documented for coastal regions of the Mackenzie Shelf and Amundsen Gulf in 2008 (Mundy et al., 2009; Tremblay et al., 2011). An annual vertical POC flux of $1.6-1.8 \mathrm{~g} \mathrm{C} \mathrm{m}^{-2} \mathrm{yr}^{-1}$ and $2.4 \mathrm{~g} \mathrm{C} \mathrm{m}^{-2} \mathrm{yr}^{-1}$ was estimated at $200 \mathrm{~m}$ water depth for the Mackenzie Shelf and the Cape Bathurst polynya, respectively (Forest et al., 2007; Lalande et al., 2009; O'Brien et al., 2006). Seafloor sediments are dominated by fine-grained material that is usually composed of more than $70 \%$ silt and clay (Conlan et al., 2008). Sediment characteristics indicate that organic carbon at the seafloor is to a large part derived from either the Mackenzie River plume and erosion (O'Brien et al., 2006) or refractory marine material (Magen et al., 2010; Morata et al., 2008; Sallon et al., 2011). The latter dominates the carbon flux in summer and on the eastern shelf (Naidu et al., 2000) whereas on the Mackenzie Shelf carbon of terrestrial origin is abundant in fall (Morata et al., 2008).

\subsection{Field sampling}

Samples were collected during the Malina programme at eight sites ranging in water depth from $47 \mathrm{~m}$ to $577 \mathrm{~m}$ in July and August 2009 onboard the icebreaker CCGS Amundsen (Table 1). At each sampling event ("station"), an USNEL box corer $(50 \mathrm{~cm} \times 50 \mathrm{~cm} \times 30 \mathrm{~cm})$ was deployed for seafloor sediment collection. From each box core, three sub-cores of $10 \mathrm{~cm}$ diameter and approximately $20 \mathrm{~cm}$ sediment depth were taken for assessing benthic oxygen demand and nutrient remineralisation in microcosm incubations. Six additional sub-cores of $2.4 \mathrm{~cm}$ diameter were taken, three of $8 \mathrm{~cm}$ and $1 \mathrm{~cm}$ length, respectively, for determining sediment pigment concentration, water content and sediment solid phase composition (Table 1). The surface samples ( 0 to $1 \mathrm{~cm}$ ) were stored in pre-weighed plastic vials and frozen immediately at $-80^{\circ} \mathrm{C}$ for later analysis. Near-bottom water temperature and salinity were determined by the shipboard CTD probe at each station $10 \mathrm{~m}$ above the seafloor. Salinity ranged from $32.2 \mathrm{PSU}$ at the shallowest site $(47 \mathrm{~m})$ to 34.9 PSU at the deepest site $(577 \mathrm{~m})$. Temperature values varied between $-1.6^{\circ} \mathrm{C}$ and $0.4{ }^{\circ} \mathrm{C}$ (Table 1).

\subsection{Sediment pigment concentration}

Chl $a$ and phaeopigment concentrations were determined fluorometrically following a modified protocol proposed by Riaux-Gobin and Klein (1993) as described in Link et al. (2011): two grams of wet substrate were extracted with $10 \mathrm{~mL} 90 \%$ acetone $(v / v)$ for $24 \mathrm{~h}$ at $4{ }^{\circ} \mathrm{C}$, and the supernatant was measured in a Turner Designs 20 fluorometer before and after acidification. Quantities are expressed as microgram pigment per gram of dry sediment $\left(\mu \mathrm{g} \mathrm{g}^{-1}\right)$.

\subsection{Surficial sediment composition and sinking particle fluxes}

Porosity was determined from weight loss upon drying the sediment sample using a dry sediment density of $2.65 \mathrm{~g} \mathrm{~cm}^{-3}$ (Berner, 1980). The weight difference between wet and dry sample was corrected for salt from seawater content using the average seawater density and the value of salinity measured in the bottom waters.

For stable isotope composition analysis, ground sediments were acidified twice for $48 \mathrm{~h}$ with a dilute $\mathrm{HCl}$ solution to dissolve solid carbonates. The acid supernatant was decanted and solids rinsed with nanopure water and dried. Samples were analysed for $\delta^{13} \mathrm{C}_{\text {org }}$ and $\delta^{15} \mathrm{~N}$ with a CF-IRMS (continuous-flow isotope ratio mass spectrometer) coupled to a Costech 4010 elemental analyser. Here, we only report the stable isotope signature of $\delta^{13} \mathrm{C}_{\text {org }}$ of the surficial buried organic matter. Data are reported in standard notation in \%o with respect to the V-PDB standard for carbon. The analytical error was lower than $0.3 \%$ and three internal standards were measured during the isotopic analyses to continuously check the accuracy of the measurements.

Acid soluble manganese oxides and iron oxides were determined on homogenised dried sediments using $1 \mathrm{M} \mathrm{HCl}$ solution. About $250 \mathrm{mg}$ of dry sample was leached with a $12 \mathrm{~mL}$ solution during $24 \mathrm{~h}$ while shaking continuously at room temperature. The centrifuged and filtered solution was then 10 -fold diluted in $0.2 \mathrm{M} \mathrm{HCl}$ and analysed with a flame atomic absorption spectrometer (5100PC PerkinElmer). The analytical precisions were better than $\pm 3 \%$ and $\pm 7 \%$ for manganese and iron, respectively. Acid soluble iron $\left(\mathrm{Fe}_{\mathrm{HCl}}\right)$ represents amorphous iron oxides, ironS, some iron phyllosilicates and iron carbonates. Specific tests on particulate manganese extraction with $1 \mathrm{M} \mathrm{HCl}$ $\left(\mathrm{Mn}_{\mathrm{HCl}}\right)$ have shown that $\mathrm{Mn}_{\mathrm{HCl}}$ represents the whole fraction of manganese oxides and manganese associated with carbonates (Anschutz et al., 2006).

Sinking fluxes of particulate organic carbon (POC) reaching the benthic boundary layer (approximately $20 \mathrm{~m}$ above bottom) were derived from a particle size distribution dataset obtained with an Underwater Vision Profiler 5 (UVP5, Picheral et al., 2010) deployed at every station (Table 1). Full methodology on the functioning of the UVP5 
Table 1. Station list. Labels, date of sampling, geographic position, bottom water temperatures and salinities, number of within-station replicate samples used to determine benthic boundary fluxes (BBF) and sediment surface properties (Chl $a$, phaeopigments, porosity, manganese and iron oxide). $\mathrm{A}=$ Amundsen Gulf; $\mathrm{MD}=$ Mackenzie Delta; $\mathrm{MS}=$ Mackenzie Shelf/Slope; $\mathrm{C}, \mathrm{E}, \mathrm{N}, \mathrm{W}=$ central, east, north, west.

\begin{tabular}{|c|c|c|c|c|c|c|c|c|c|}
\hline Station & $\begin{array}{l}\text { Malina } \\
\text { station } \\
\text { label }\end{array}$ & Date & $\begin{array}{l}\text { Depth } \\
{[\mathrm{m}]}\end{array}$ & $\begin{array}{c}\text { Latitude } \\
{\left[{ }^{\circ} \mathrm{N}\right]}\end{array}$ & $\begin{array}{c}\text { Longitude } \\
{\left[{ }^{\circ} \mathrm{W}\right]}\end{array}$ & $\mathrm{Sal}_{\text {bot }}$ & $\begin{array}{l}T_{\text {bot }} \\
{\left[{ }^{\circ} \mathrm{C}\right]}\end{array}$ & $\begin{array}{l}\mathrm{BBF} \\
(n)\end{array}$ & $\begin{array}{l}\text { Sed Prop } \\
\quad(n)\end{array}$ \\
\hline MD-C & 390 & 31 Jul 2009 & 47 & 70.178 & 133.569 & 32.24 & -1.3 & 3 & 3 \\
\hline MD-W & 690 & 1 Aug 2009 & 55 & 69.486 & 137.942 & 32.49 & -1.6 & 3 & 3 \\
\hline MD-E & 260 & 4 Aug 2009 & 60 & 71.269 & 130.613 & 32.32 & -1.2 & 3 & 3 \\
\hline A-NW & 110 & 6 Aug 2009 & 400 & 71.696 & 126.477 & 34.77 & 0.3 & 3 & 3 \\
\hline \multirow[t]{2}{*}{$\mathrm{A}-\mathrm{CW}$} & 140 & 7 Aug 2009 & 154 & 71.285 & 127.783 & 33.40 & -1.4 & 1 & 1 \\
\hline & & & 154 & 71.285 & 127.782 & & & 2 & 2 \\
\hline MS-W & 680 & 10 Aug 2009 & 125 & 69.611 & 138.235 & 32.31 & -1.3 & 3 & 3 \\
\hline MS-C & 345 & 16 Aug 2009 & 577 & 71.382 & 132.652 & 34.86 & 0.2 & 3 & 3 \\
\hline MS-E & 235 & 22 Aug 2009 & 576 & 71.764 & 130.766 & 34.84 & 0.4 & 3 & 3 \\
\hline
\end{tabular}

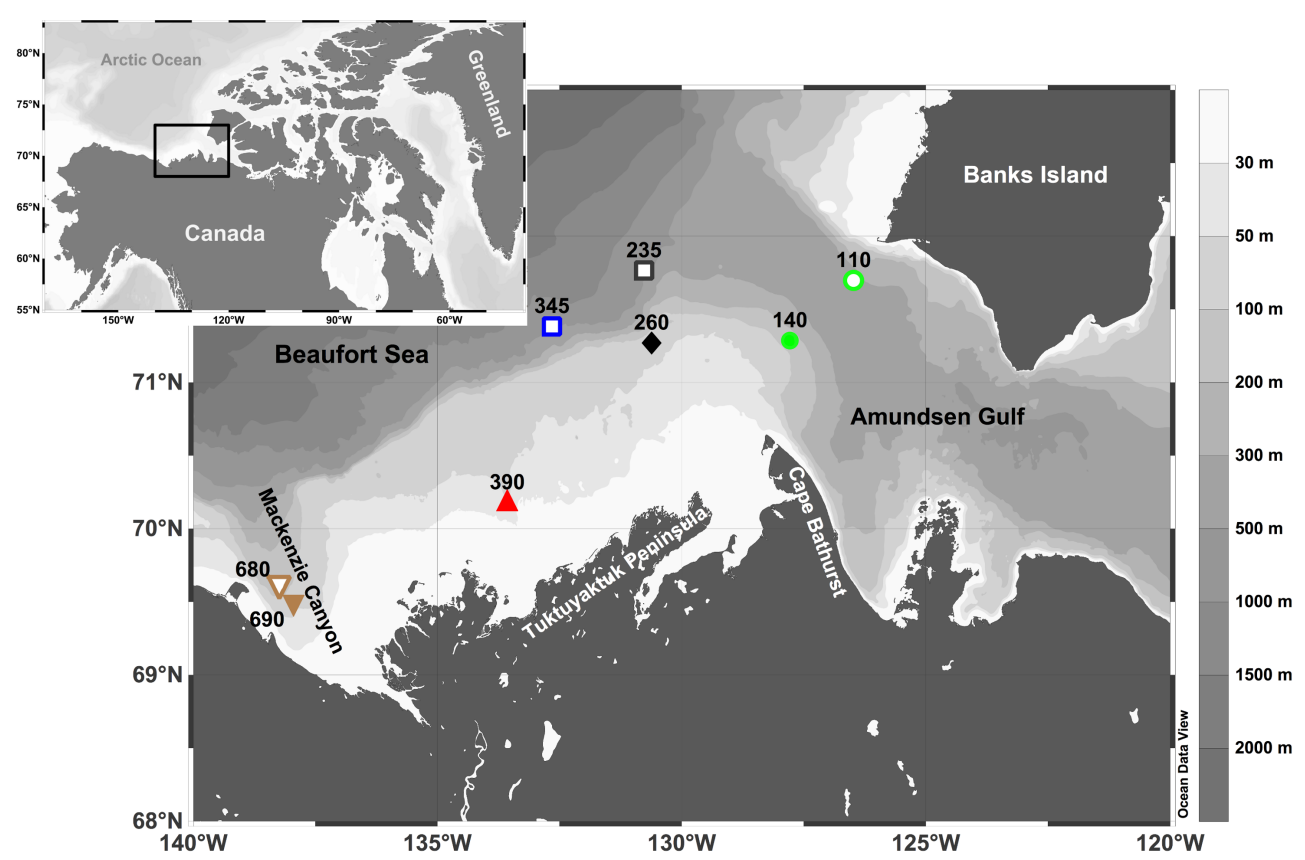

Fig. 1. Locations of sites sampled for benthic boundary fluxes during the Malina expedition in the Beaufort Sea in summer 2009.

and on the estimation of sinking POC fluxes can be found in Forest et al. (2013). Briefly, particles in the range 0.08$4.2 \mathrm{~mm}$ (in equivalent spherical diameter) recorded with the UVP5 were transformed into sinking fluxes by applying a regional empirical algorithm linking sediment trap fluxes and the UVP5 dataset. The algorithm was calibrated using an optimization function following Guidi et al. (2008) and provided robust agreement between sediment trap POC fluxes and UVP5 POC fluxes $\left(r^{2}=0.68, n=21\right)$.

\subsection{Benthic oxygen flux and nutrient remineralisation}

Incubations of sediment microcosms were run in a dark, temperature-controlled room $\left(2\right.$ to $\left.4^{\circ} \mathrm{C}\right)$ for 24 to $48 \mathrm{~h}$. Prior to the onset of measurements, sediment cores were carefully topped with bottom water collected by Niskin bottles of the shipboard CTD-rosette at the same site, and then allowed to acclimate for six to eight hours while being saturated with oxygen to avoid suboxic conditions during incubations. At the onset of measurements, the microcosms were hermetically closed and bubbles were removed. During the incubation, the water overlying the sediment was constantly stirred without resuspending the sediment surface. 
Total sediment oxygen flux was determined as the change in oxygen concentrations in the water phase and was measured periodically ( 2 to $8 \mathrm{~h}$ intervals) with a noninvasive optical probe (Fibox 3 LCD, PreSens, Regensburg, Germany). Incubations were stopped when oxygen levels had decreased by more than $20 \%$ to avoid hypoxic conditions and biogeochemical transformations. Hall et al. (1989) demonstrated the importance of maintaining the $\mathrm{O}_{2}$ supply to obtain consistent and relevant data during core incubations.

To determine changes in nutrient concentration, samples of the overlying water phase were taken at three times during the incubation, including the onset and end. Water samples withdrawn for analysis were immediately replaced by an equivalent volume of bottom water of known nutrient composition. The total amount of water withdrawn and replaced during each sampling never exceeded $10 \%$ of the total overlying water volume to prevent artefacts. Three additional incubation cores containing bottom water only acted as controls for assessing the oxygen consumption and nutrient changes due to processes within the water column or sample handling. Oxygen and nutrient fluxes were determined as the slope of the linear regression of the oxygen and nutrient concentration on incubation time and corrected for solute concentration in the replacement water. Median flux rates determined in the three control cores were subtracted from each sediment core measure. A positive boundary flux means a release of the nutrient from sediment into the water column.

Samples were filtered through combusted GF/F filters and split into subsamples for nutrient analyses. For $\mathrm{NH}_{4}^{+}$ measurements, $6 \mathrm{~mL}$ samples were immediately incubated with $3 \mathrm{~mL}$ orthophtaldialdehyde solution following an adaptation of the method proposed by Holmes et al. (1999). Samples were analysed using a Turner Designs fluorometer $5-6 \mathrm{~h}$ after the initiation of colorimetric reaction. Detection limit for ammonium was $0.1 \mu \mathrm{M}$. For nitrate, nitrite, phosphate and silicic acid measurements, water samples were frozen at $-80^{\circ} \mathrm{C}$ and analysed within the following two weeks using an Autoanalyzer 3 (Bran and Luebbe) applying colorimetric methods adapted from Grasshoff et al. (1999). The precision of these methods was $\pm 5 \%$.

\subsection{Definition of short-term and long-term environmental factors}

We used environmental parameters of different temporal variation to explain benthic boundary fluxes. As short-term scale we define seasonal to annual timescales and include the parameters sediment surface $\mathrm{Chl} a$ concentration and vertical POC export. Results reported from different seasons and years in the Beaufort Sea have shown that sediment Chl $a$ concentration and vertical POC export vary both over seasons and years (Forest et al., 2007; Juul-Pedersen et al., 2010; Link et al., 2011; Morata et al., 2008; Renaud et al., 2007a; Sallon et al., 2011), respectively. This is due to the seasonal and spatial dynamics of primary production and carbon fluxes in the region (Forest et al., 2010; OrtegaRetuerta et al., 2012; Tremblay et al., 2011).

As long-term scale we define temporal variations of decades and longer. Bottom water oxygen concentration of shelf waters changes on such timescales (Gilbert et al., 2005, 2010), as does iron oxide (Hensen et al., 2006) and manganese oxide concentration (Gobeil et al., 2001; Katsev et al., 2006) in sediments. In open ocean regions, changes in the ocean's dissolved oxygen are likely related to physical processes and thermohaline circulation. The major drivers of these changes are increased temperature, altered hydrological cycles and shifts in wind patterns that alter coastal currents and upwelling formation (Rabalais et al., 2009). The effect of interdecadal changes in deep-water characteristics have recently been proposed to explain a decline in dissolved oxygen saturation in deep waters of both coastal waters (Chan et al., 2008; Gilbert et al., 2005) and open basins (Fukasawa et al., 2004). At the sediment-water interface, the abundance of trace metals such as manganese oxides and iron oxides allows us to track the depositional redox conditions (Tribovillard et al., 2006). Sedimentary redox conditions reflect the balance between the $\mathrm{O}_{2}$ diffusing from the bottom water and metabolic aerobic processes that mineralise the labile organic carbon at the sediment-water interface (Canfield et al., 1993; Froelich et al., 1979). Over a period of several decades, the upward migration of the sedimentary redox boundary can generate a surficial peak of metal oxides as a result of generally increased water column productivity (Gobeil et al., 2001; Katsev et al., 2006) or progressive decline in the deep water oxygen saturation (Lefort et al., 2012). Changes in porosity of sediments depends on several factors including sedimentation rate and sediment composition. Average sedimentation rate of $\sim 1 \mathrm{~mm} \mathrm{yr}^{-1}$ (Bringué and Rochon, 2012; Richerol et al., 2008) has been reported. It integrates potential seasonal variations in grain size and sedimentation, and current data does not indicate high annual variation. Long-term trends in Mackenzie River run-off have not changed markedly within the last decades (Durantou et al., 2012), and there is little to no change in sediment properties, including grain size, over the last centuries (Bringué and Rochon, 2012). We therefore consider porosity as relatively constant over decadal and century scales and a long-term variable.

Sediment phaeopigment concentration depends on vertical POC flux (short-term factor) but is also the accumulation of degraded material over several years (Morata et al., 2008). The signature of $\delta^{13} \mathrm{C}$ in surface sediments depends on the contribution of terrestrial versus marine produced carbon to the total carbon input and rather indicates input of sediments from the Mackenzie River (Goñi et al., 2005; Magen et al., 2010; Naidu et al., 2000). Therefore, sediment phaeopigment concentration and $\delta^{13} \mathrm{C}$ signature are considered "other" environmental factors. 
Table 2. Fluxes of oxygen $\left(\mathrm{O}_{2}\right)$, silicic acid $\left(\mathrm{Si}(\mathrm{OH})_{4}\right)$, phosphate $\left(\mathrm{PO}_{4}^{2-}\right)$, nitrate $\left(\mathrm{NO}_{3}^{-}\right)$, nitrite $\left(\mathrm{NO}_{2}^{-}\right)$, and ammonium $\left(\mathrm{NH}_{4}^{+}\right)$across the sediment-water interface determined for three replicates at eight stations in the southeastern Beaufort Sea in July/August 2009.

\begin{tabular}{|c|c|c|c|c|c|c|}
\hline $\begin{array}{l}\text { Malina } \\
\text { label }\end{array}$ & $\begin{array}{r}\mathrm{O}_{2} \text { flux } \\
{\left[\mathrm{mmol} \mathrm{m}^{-2} \mathrm{~d}^{-1}\right]}\end{array}$ & $\begin{array}{r}\mathrm{Si}(\mathrm{OH})_{4} \\
{\left[\mu \mathrm{mol} \mathrm{m}{ }^{-2} \mathrm{~d}^{-1}\right]}\end{array}$ & 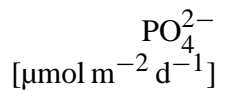 & {$\left[\mu \mathrm{mol} \mathrm{m}^{-2} \mathrm{~d}_{3}^{-1}\right]$} & {$\left[\mu \mathrm{mol} \mathrm{m}{ }^{-2} \mathrm{~d}^{-1}\right]$} & {$\left[\mu \mathrm{mol} \mathrm{m}{ }^{-2} \mathrm{~d}^{-1}\right]$} \\
\hline \multirow[t]{3}{*}{390} & -9.51 & $-352.13 *$ & -41.07 & -785.06 & -25.84 & -44.61 \\
\hline & -11.47 & 3494.65 & 23.25 & -597.91 & -4.28 & 281.00 \\
\hline & -10.59 & 2478.59 & -44.26 & -378.09 & 14.39 & 443.30 \\
\hline \multirow[t]{3}{*}{690} & -8.84 & 1171.44 & -46.35 & -345.32 & -43.57 & -30.80 \\
\hline & -8.13 & 1082.16 & -57.66 & -631.51 & -15.90 & -66.95 \\
\hline & -8.48 & 947.69 & -39.14 & -324.24 & -29.15 & 31.38 \\
\hline \multirow[t]{3}{*}{260} & -5.41 & 2092.55 & 17.29 & 10.59 & -7.10 & 21.24 \\
\hline & -4.29 & 1347.74 & 27.55 & 21.24 & -7.49 & 60.89 \\
\hline & -3.42 & 1377.07 & 15.51 & 41.35 & -7.94 & -53.54 \\
\hline \multirow[t]{3}{*}{110} & -0.98 & 867.21 & 3.21 & 90.24 & -3.24 & 4.35 \\
\hline & -1.31 & 763.65 & 0.38 & -27.85 & -3.51 & -13.74 \\
\hline & -0.70 & 599.41 & -0.85 & -22.68 & -1.99 & 5.19 \\
\hline \multirow[t]{3}{*}{140} & -3.26 & 1776.83 & 13.24 & 16.45 & -2.76 & -56.18 \\
\hline & -2.41 & 1798.87 & 15.24 & 362.94 & -9.93 & -54.90 \\
\hline & -2.33 & 2819.58 & 40.67 & 193.84 & -0.77 & -48.62 \\
\hline \multirow[t]{3}{*}{680} & -4.32 & 1283.23 & 11.08 & -238.66 & -3.37 & -10.52 \\
\hline & -5.04 & 1356.21 & 19.59 & -120.99 & 0.18 & 6.75 \\
\hline & -4.45 & 1232.46 & 17.25 & -158.03 & -3.08 & -13.49 \\
\hline \multirow[t]{3}{*}{345} & -0.53 & 437.34 & 13.40 & 92.78 & -0.65 & 1.02 \\
\hline & -0.54 & 329.21 & 9.32 & -2.08 & -0.45 & -2.68 \\
\hline & -0.81 & 481.38 & 6.20 & 25.01 & 3.40 & 3.25 \\
\hline \multirow[t]{3}{*}{235} & -0.86 & 363.63 & -0.37 & -24.75 & -1.39 & -16.58 \\
\hline & -0.63 & 457.30 & 5.90 & 132.52 & -2.09 & -14.16 \\
\hline & -0.52 & 314.54 & 0.56 & -26.89 & -1.71 & -16.37 \\
\hline
\end{tabular}

* Denotes an outlier that has been excluded from statistical analyses following Cook's distance analysis. Data is graphically presented in Fig. 2.

\subsection{Statistical analyses}

We used best-subset multiple regression analyses to identify potential drivers of each single flux separately. Predicting variables allowed in the model were content of $\mathrm{Chl} a$, phaeopigment, manganese oxides and iron oxides in surface sediments, sediment surface porosity and $\delta^{13} \mathrm{C}_{\text {org }}$ as well as bottom water oxygen concentration. Due to independent sampling of environmental and benthic flux data, the median value of each site of each of the predicting variables was attributed to the three flux replicates of each site. This allowed for keeping the high variability of benthic boundary fluxes in the model testing. Analysis of multicollinearity showed that sediment $\mathrm{Chl} a$ concentration and sinking POC in the lower water column were highly correlated $(R=0.92)$. Nevertheless, both predictors were retained in the initial full multiple regression model to determine which of the two would be predictors in the best solutions. Akaike's information criterion (AIC) was applied to choose the best linear model (Akaike, 1978; Quinn and Keough,
2002). In none of the best models, both predictors were retained. Normal distribution of the best model's residuals was verified with the Shapiro-Wilk test, and homogeneity of variance was tested using graphical methods (Quinn and Keough, 2002). If distribution of residuals was skewed, natural logarithm transformation was applied to the response variable and/or sediment surface Chl $a$ and sinking POC data until assumptions were met by the best model. Normality could not be achieved for any $\mathrm{NO}_{2}^{-}$model, thus only the graphical method was applied. Outliers with severe influence on the model were identified using Cook's distance $(D)$ and removed if $D>1$. One outlier in the silicic acid fluxes was found and removed from all further analyses (Table 2). We tested for collinearity of variables retained in the bestsubset model using the variance inflation factor (VIF), with VIF $>10$ indicating critical collinearity (Quinn and Keough, 2002). This was not the case for any of the best-subset models.

Principal component analysis (PCA) was used to determine the influence (eigenvector) of the six measured 
benthic boundary fluxes on the ordination of samples in a multidimensional space. Prior to PCA, homogeneity of each variable was assessed using a draftsman plot, and ammonium fluxes were transformed using natural logarithm. Moreover, flux data was standardized using the "normalise" routine in PRIMER-E (Clarke and Gorley, 2006). No pair of fluxes was correlated with $R>0.7$, with the exception of nitrate and oxygen $(R=0.82)$.

A stepwise distance-based linear model permutation test (DistLM, McArdle and Anderson, 2001) was performed to identify which set of environmental variables predict the multivariate variation of benthic boundary fluxes, thus taking into account possible interactions between different fluxes (in contrast to the multiple regression approach described above). The resemblance matrix quantifying the betweensample similarities in terms of all six standardized fluxes was calculated based on Euclidean distances (Clarke and Gorley, 2006). Predicting environmental variables allowed to enter the model were content of $\mathrm{Chl} a$, phaeopigment, manganese oxides and iron oxides in surface sediments, sediment surface porosity and $\delta^{13} \mathrm{C}_{\text {org }}$ as well as bottom water oxygen concentration. To represent natural variation as much as possible in the analysis but to avoid arbitrary attribution, each environmental sample of a site was attributed to each replicate flux sample, thus triplicating the original dataset. Sinking POC rates were excluded from this analysis due to a lack of replicates and due to its correlation with sediment $\mathrm{Chl} a$. While the influence of multicollinearity on the model results can be tested for multiple regression (VIF, see above), this is not the case for the DistLM. After assessing normality and collinearity of the other predictor variables using a draftsman plot, sediment $\mathrm{Chl} a$ data was transformed using the natural logarithm to correct for skewness (Anderson et al., 2008). No pair of variables was correlated by $R>0.85$ and hence all variables were retained for possible inclusion in the model. The stepwise routine was run employing 9999 permutations and using the $\mathrm{AIC}_{\mathrm{c}}$ (Akaike's information criterion corrected) selection criterion. The $\mathrm{AIC}_{\mathrm{c}}$ was devised to handle situations where the number of samples $(N)$ is small relative to the number $(v)$ of predictor variables $(N / v<40)$ (Anderson et al., 2008). Results were visualized with a distance-based redundancy analysis (dbRDA) (Anderson et al., 2008). All multivariate statistical analyses were performed using the PRIMER 6 statistical package with the PERMANOVA+ add-on (PRIMER-E, Plymouth Marine Laboratory, UK).

\section{Results}

\subsection{Spatial variability and benthic boundary fluxes dominating the variation among sites}

Sediment oxygen uptake varied between 0.5 and $11.5 \mathrm{mmol}$ $\mathrm{O}_{2} \mathrm{~m}^{-2} \mathrm{~d}^{-1}$ with the highest values in the shallower central
Table 3. Correlation-based principal component analysis (PCA) of normalised benthic boundary fluxes determined in the southeastern Beaufort Sea in July/August 2009. Eigenvalues and \% of variation explained by the first 5 ordination axes (PC1, PC2, PC3, PC4, and $\mathrm{PC} 5$ ) is given. Linear coefficients (eigenvector) of each $\mathrm{PC}$ are given for each flux.

\begin{tabular}{lrrrrr}
\hline & PC1 & PC2 & PC3 & PC4 & PC5 \\
\cline { 2 - 6 } Eigenvalue & 2.77 & 1.64 & 0.88 & 0.46 & 0.22 \\
\% variation & 46.2 & 27.4 & 14.7 & 7.7 & 3.6 \\
\hline Eigenvector & & & & & \\
$\mathrm{O}_{2}$ & -0.548 & 0.295 & 0.092 & 0.011 & 0.055 \\
$\mathrm{Si}(\mathrm{OH})_{4}$ & 0.170 & -0.612 & -0.564 & 0.047 & -0.287 \\
$\mathrm{PO}_{4}^{2-}$ & -0.470 & -0.306 & -0.343 & -0.269 & 0.670 \\
$\mathrm{NO}_{3}^{-}$ & -0.543 & 0.065 & -0.177 & -0.314 & -0.677 \\
$\mathrm{NO}_{2}^{-}$ & -0.394 & -0.376 & 0.252 & 0.779 & -0.062 \\
$\mathrm{NH}_{4}^{+}(\ln )$ & -0.017 & -0.546 & 0.679 & -0.470 & -0.062 \\
\hline
\end{tabular}

Mackenzie Delta (390) and the lowest values on the deeper eastern and central Mackenzie Slope (110, 235, and 345; Fig. 2, Table 2). This spatial pattern was generally also evident in the release of silicic acid from the sediments (314.5-3494.7 $\mu \mathrm{mol} \mathrm{m}^{-2} \mathrm{~d}^{-1}$, Table 2), although fluxes at sites at comparable water depths were higher in the eastern study area (Fig. 2). Phosphate was taken up by the sediments at the shallowest sites off the western and central Mackenzie Delta (690 and 390) and mostly released at all other sites (Fig. 2). Nitrate was mostly released from the sediments at eastern sites, while the shelf sites off the central and western Mackenzie Delta were characterized by high sediment uptake rates of nitrate (Fig. 2, Table 2). Uptake fluxes were found in most nitrite measurements, being highest off the shallow Mackenzie Shelf. Ammonium showed the highest release rates recorded from station 390 on the shallower central Mackenzie Shelf and highest uptake rates found in the Cape Bathurst polynya at station 140 (Fig. 2, Table 2). Within site, variability of phosphate and all three nitrogenderived fluxes was higher than for silicic acid and oxygen fluxes (Fig. 2, Table 2).

In the PCA plot, variation was high between the central (390) and western (690) Mackenzie Delta and all other samples, and low among deeper Mackenzie Shelf and Amundsen Gulf samples $(235,345,110,140)$ (Fig. 3). The first PCA axis (PC1) explained $46.2 \%$ of the total variance in the flux data, and the first three PCA axes (PC1, PC2, and PC3) together explained $88.3 \%$ (Table 3). Analysis of the eigenvectors showed that no single flux dominated the multivariate similarity pattern among samples (Fig. 3). Oxygen, phosphate and nitrate fluxes were most correlated with the first PCA axis, while silicic acid and ammonium fluxes showed a closer relationship to PC2 and PC3. Nitrite fluxes correlated almost equally with all PCA axes (Table 3, Fig. 3). 

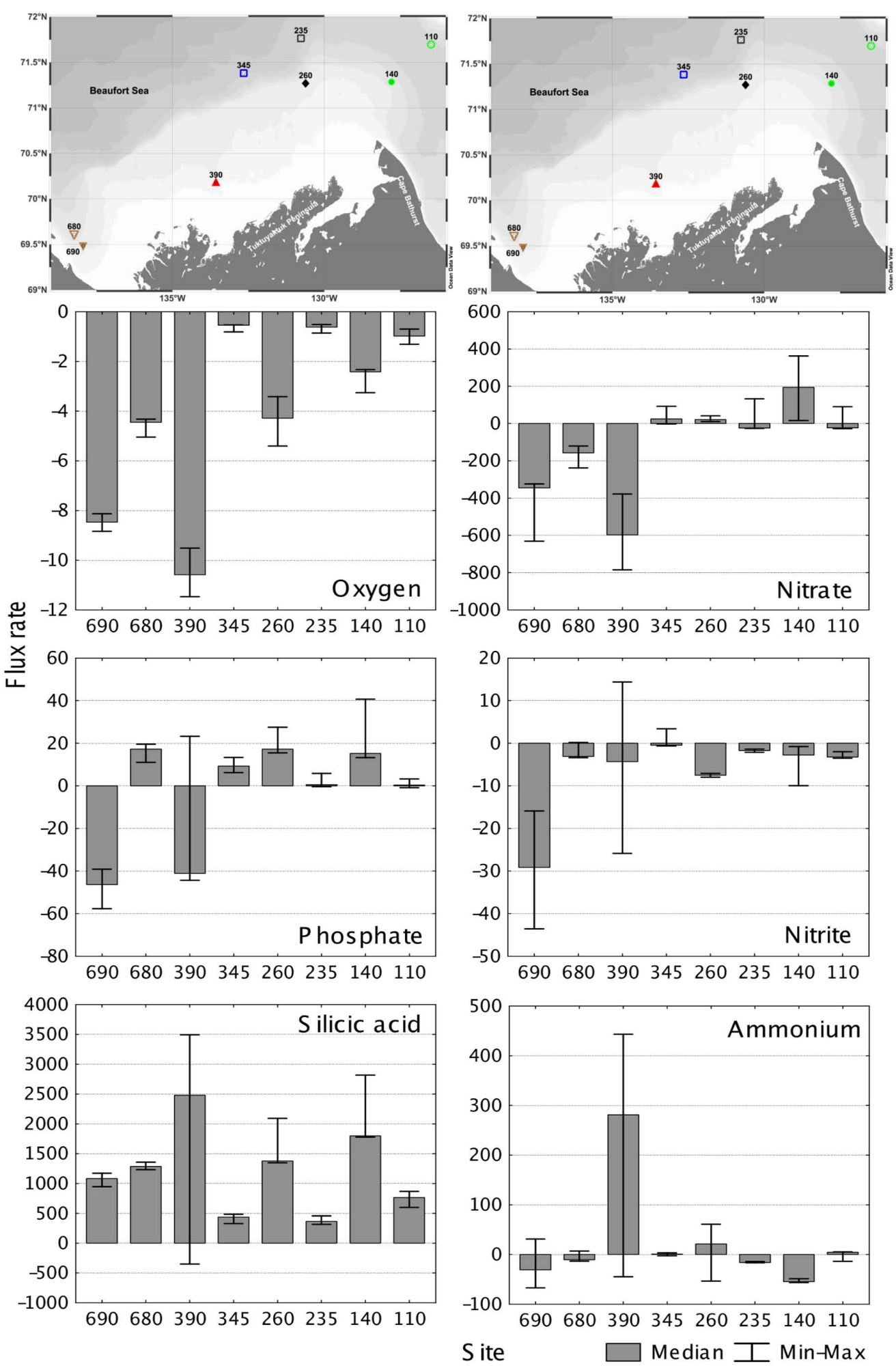

Fig. 2. Benthic boundary fluxes in the southeastern Beaufort Sea in relation to their location. Flux rates are presented in $\mathrm{mmol} \mathrm{m}^{-2} \mathrm{~d}^{-1}$ for oxygen and in $\mu \mathrm{mol} \mathrm{m}{ }^{-2} \mathrm{~d}^{-1}$ for all other fluxes. The values of three replicates (median, minimum and maximum) from each site are shown along the y-axis. Positive values indicate release from sediments, negative values uptake by sediments; the deviation level is a reference to the zero plane. See Table 2 for exact data. 


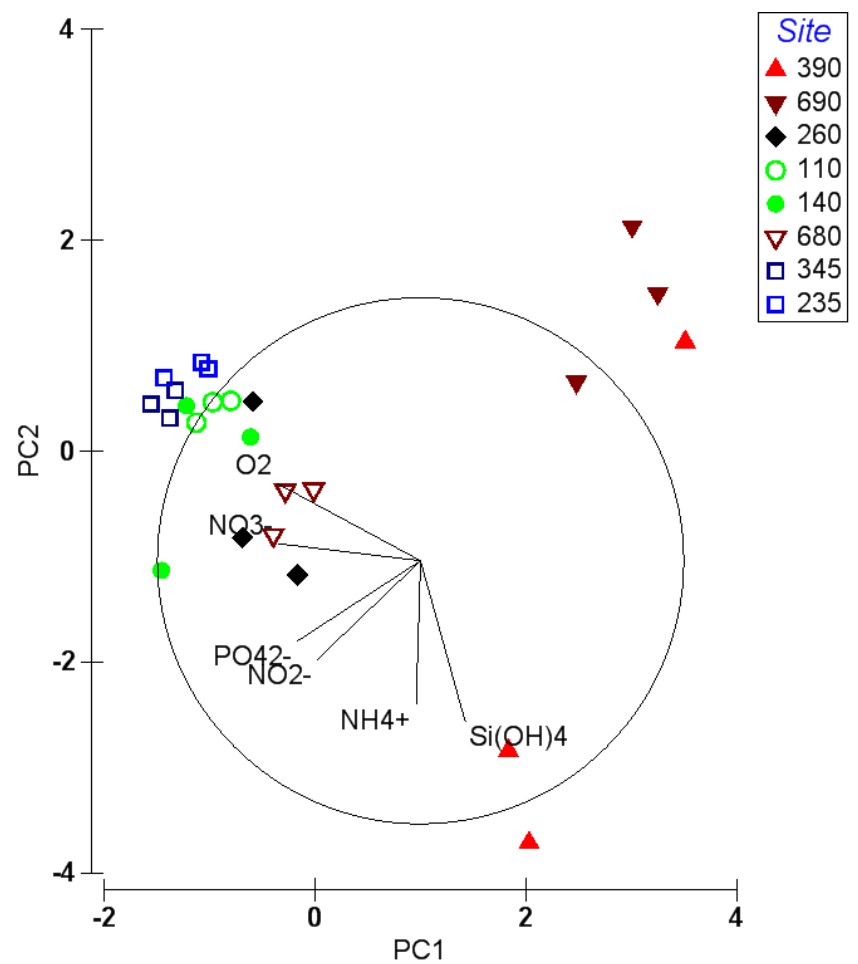

Fig. 3. Principal component analysis (PCA) plot showing the nonmetric multivariate similarity among replicate samples in terms of benthic boundary fluxes. Vectors indicate the direction and strength of each flux's contribution to the overall distribution (Table 3). Brown and red triangles: shallow Mackenzie Shelf and Delta; green circles: Cape Bathurst and Amundsen Gulf region (east); blue squares: deeper Mackenzie Slope.

\subsection{Environmental drivers of spatial flux variation for single fluxes}

Results of environmental parameters used for statistical analyses are presented in Table 4 . The best models explaining variation in each benthic boundary flux are shown in Table 5 . Except for ammonium and nitrite fluxes, more than $68 \%$ of the variation in each flux could be explained by the environmental predictors (Table 5). Oxygen uptake strongly increased with vertical water-column POC flux, increased with sediment phaeopigment concentration and decreased with the porosity and concentration of iron oxide in surface sediments (adjusted (adj.) $R^{2}=0.98, p<0.001$ ). Release of silicic acid decreased with phaeopigment concentrations but rose with sediment $\mathrm{Chl} a$ and bottom water oxygen concentrations (adj. $R^{2}=0.92, p<0.001$ ). Phosphate fluxes strongly increased with $\delta^{13} \mathrm{C}$ signature and declined with sediment manganese oxide concentrations and with vertical POC flux (adj. $R^{2}=0.68, p<0.001$ ). Nitrate fluxes were best predicted by $\delta^{13} \mathrm{C}$ signature (positive), sediment manganese oxide and $\mathrm{Chl} a$ concentration (both negative, adj. $\left.R^{2}=0.81, p<0.001\right)$. Nitrite fluxes increased with

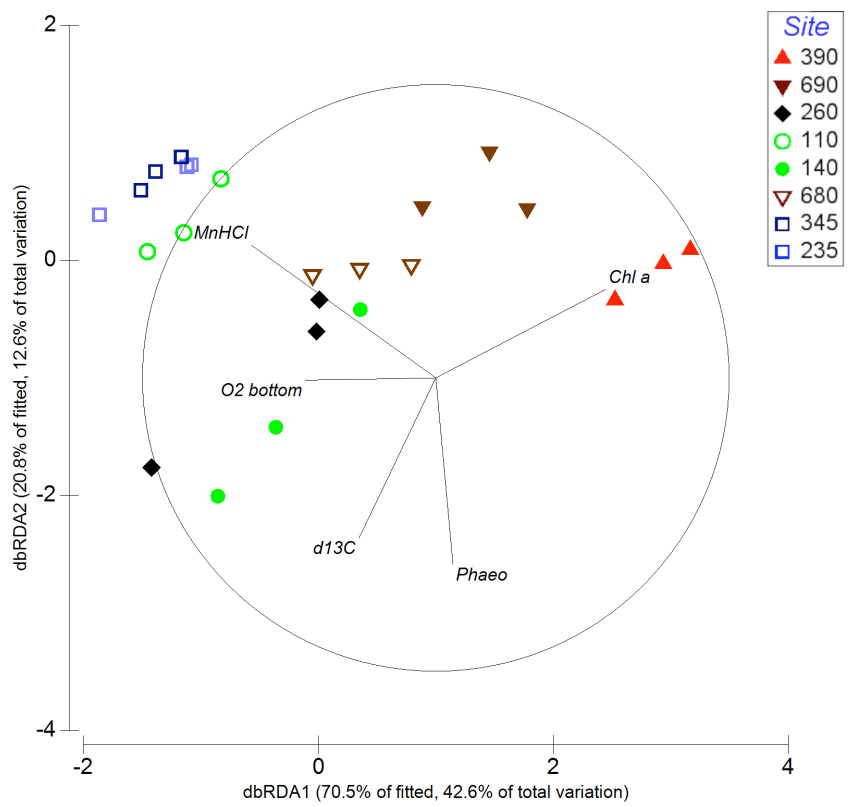

Fig. 4. Distance-based redundancy analysis (dbRDA) plot of the DistLM based on the environmental parameters fitted to the variation in biogeochemical fluxes (Table 6). Vectors indicate direction of the parameter effect in the ordination plot. Chl $a=$ natural logarithm of sediment $\mathrm{Chl} a$ concentration; $\mathrm{dC} 13=\delta^{13} \mathrm{C}$ signature; Phaeo = sediment phaeopigment concentration; $\mathrm{Mn}_{\mathrm{HCl}}=$ sediment surface manganese oxide concentration; and $\mathrm{O}_{2}$ bottom $=$ bottom water oxygen concentration. Brown and red triangles: shallow Mackenzie Shelf and Delta; green circles: Cape Bathurst and Amundsen Gulf region (east); blue squares: deeper Mackenzie Slope.

$\delta^{13} \mathrm{C}$ signature, bottom water oxygen levels and sediment porosities (adj. $R^{2}=0.50, p=0.002$ ). Finally, ammonium release was found to strongly increase with $\mathrm{Chl} a$ and phaeopigment concentrations but to decrease with $\delta^{13} \mathrm{C}$ signature (adj. $\left.R^{2}=0.24, p=0.037\right)$.

\subsection{Influence of environmental parameters on the overall distribution of benthic remineralisation function}

The best distance-based linear model, explaining $57 \%$ of the overall variation in benthic boundary fluxes, is composed of sediment surface $\mathrm{Chl} a$, phaeopigment and manganese oxide concentration, $\delta^{13} \mathrm{C}$ signature and bottom water oxygen concentration (Fig. 4, Table 6). The most important parameters contributing to the first axis of the dbRDA plot (explaining $70.5 \%$ of fitted flux variation), which separates shallower and western sites from deeper and eastern sites, are sediment surface $\mathrm{Chl} a$ and manganese oxide concentration and bottom water oxygen concentration (Fig. 4). They explain more than $40 \%$ of the total variation (Table 6). Sediment phaeopigment concentration and $\delta^{13} \mathrm{C}$ 
Table 4. Replicate values of abiotic parameters measured in the overlying bottom water and at the sediment surface used as environmental variables tested to explain the distribution of the benthic fluxes. Dissolved oxygen (DBO), porosity, manganese oxide $\left(\mathrm{Mn}_{\mathrm{HCl}}\right)$ and iron oxide $\left(\mathrm{Fe}_{\mathrm{HCl}}\right)$ contents, stable isotope signature of the surficial organic matter $\left(\delta^{13} \mathrm{C}_{\mathrm{org}}\right)$, and pigment $(\mathrm{Chl} a$ and phaeopigments Phaeo) contents are presented. Sinking POC estimated at the bottom of the water column by Forest et al. (2013).

\begin{tabular}{|c|c|c|c|c|c|c|c|c|c|}
\hline $\begin{array}{l}\text { Malina } \\
\text { label }\end{array}$ & $\begin{array}{c}\mathrm{DBO} \\
\mu \mathrm{M}\end{array}$ & Porosity & $\begin{array}{c}\mathrm{Mn}_{\mathrm{HCl}} \\
\mu \mathrm{mol} \mathrm{g}^{-1}\end{array}$ & $\begin{array}{c}\mathrm{Fe}_{\mathrm{HCl}} \\
\mu \mathrm{mol} \mathrm{g}^{-1}\end{array}$ & $\begin{array}{c}\delta^{15} \mathrm{~N}_{\text {tot }} \\
\% \text { o }\end{array}$ & $\begin{array}{c}{ }^{13} \mathrm{C}_{\text {org }} \\
\% \circ\end{array}$ & $\begin{array}{c}\text { Chl } a \\
\mu \mathrm{gg}^{-1}\end{array}$ & $\begin{array}{l}\text { Phaeo } \\
\mu g^{-1}\end{array}$ & $\begin{array}{c}\text { Sinking } \\
\text { POC }\end{array}$ \\
\hline \multirow[t]{3}{*}{390} & 270 & 0.87 & 6.10 & 337.78 & 4.72 & -26.22 & n.d. & n.d. & 3441.1 \\
\hline & 271 & 0.86 & 3.94 & 347.38 & 3.96 & -26.11 & 3.81 & 9.15 & \\
\hline & 272 & 0.89 & 8.63 & 363.67 & 5.45 & -26.04 & 3.89 & 10.91 & \\
\hline \multirow[t]{3}{*}{690} & 308 & 0.83 & 19.13 & 315.82 & 3.79 & -26.57 & 1.11 & 5.13 & 1465.3 \\
\hline & 308 & 0.82 & 22.52 & 322.47 & 7.15 & -26.55 & 1.23 & 7.23 & \\
\hline & 308 & 0.80 & 10.31 & 324.31 & 4.72 & -25.96 & 1.68 & 5.73 & \\
\hline \multirow[t]{3}{*}{260} & 311 & 0.78 & 2.49 & 264.04 & 5.32 & -25.39 & 1.23 & 11.37 & 734.3 \\
\hline & 311 & 0.78 & 2.75 & 246.73 & 7.01 & -25.55 & 1.03 & 6.05 & \\
\hline & 311 & 0.78 & n.d. & 208.47 & 5.45 & -25.75 & 1.43 & 8.18 & \\
\hline \multirow[t]{3}{*}{110} & 273 & 0.81 & 85.09 & 355.27 & 6.74 & -24.00 & 0.13 & 3.56 & 20.5 \\
\hline & 273 & 0.83 & n.d. & 355.46 & 7.81 & -24.45 & 0.09 & 2.92 & \\
\hline & 273 & 0.85 & 88.56 & 355.27 & 7.12 & -24.08 & 0.15 & 4.63 & \\
\hline \multirow[t]{3}{*}{140} & 282 & 0.82 & n.d. & 309.17 & 5.54 & -25.27 & 0.86 & 6.31 & 49.8 \\
\hline & 282 & 0.86 & 36.81 & 408.35 & 6.49 & -25.39 & 1.36 & 10.81 & \\
\hline & 282 & 0.87 & 16.02 & 427.64 & 6.00 & -25.22 & 0.90 & 10.70 & \\
\hline \multirow[t]{3}{*}{680} & 303 & 0.80 & 3.42 & 312.42 & 4.42 & -26.41 & 2.95 & 9.25 & 619.2 \\
\hline & 303 & 0.76 & 3.32 & 318.53 & 3.86 & -25.96 & 1.99 & 7.29 & \\
\hline & 303 & 0.73 & 8.76 & 294.95 & 4.55 & -25.49 & 1.67 & 6.28 & \\
\hline \multirow[t]{3}{*}{345} & 299 & 0.81 & 48.72 & 334.90 & 5.77 & -25.12 & 0.04 & 1.27 & 17.8 \\
\hline & 300 & 0.76 & 59.84 & 324.99 & 5.66 & -24.55 & 0.08 & 2.24 & \\
\hline & 301 & 0.81 & 47.83 & 347.42 & 5.76 & -25.36 & 0.03 & 1.87 & \\
\hline \multirow[t]{3}{*}{235} & 298 & 0.80 & 64.85 & 303.59 & 5.63 & -27.37 & 0.52 & 8.89 & 28.3 \\
\hline & 298 & 0.80 & 61.89 & 323.67 & 5.68 & -24.89 & 0.07 & 1.87 & \\
\hline & 298 & 0.85 & 59.29 & 328.23 & 5.77 & -24.72 & 0.02 & 1.71 & \\
\hline
\end{tabular}

Table 5. Multiple regression analysis of benthic boundary fluxes against environmental factors in the southeastern Beaufort Sea in July/August 2009. Adjusted (adj.) $R^{2}$ and standardized regression coefficients of benthic parameters (short-term variability proxies: Chl $a=$ sediment chlorophyll $a$ concentration, POC = sinking POC; other variability proxies: Phaeo = sediment phaeopigment concentration, $\delta^{13} \mathrm{C}_{\mathrm{org}}=$ isotopic signature of organic carbon; long-term variability proxies: $\mathrm{Mn}_{\mathrm{HCl}}=$ sediment surface manganese oxide concentration, $\mathrm{Fe}_{\mathrm{HCl}}=$ sediment surface iron oxide concentration, $\mathrm{Po}=$ porosity, $\mathrm{O}_{2}$ bot $=$ bottom water oxygen concentration) predicting each benthic boundary flux. Whole model results are presented for the best-subset solution following Akaike's criterion (Effects = number of parameters included in the model). Absence of standardized regression coefficients indicates that the parameter was not retained in the model.

\begin{tabular}{|c|c|c|c|c|c|c|c|c|c|c|c|c|c|}
\hline \multirow[b]{2}{*}{ Flux } & \multirow[b]{2}{*}{ Adj. $R^{2}$} & \multirow[b]{2}{*}{$F$} & \multirow[b]{2}{*}{$p$} & \multicolumn{2}{|c|}{ Short-term } & \multicolumn{2}{|c|}{ Other } & \multicolumn{4}{|c|}{ Long-term } & \multirow[b]{2}{*}{ AIC } & \multirow[b]{2}{*}{ Effects } \\
\hline & & & & Chl $a$ & POC & Phaeo & ${ }^{13} \mathrm{C}_{\text {org }}$ & $\mathrm{Mn}_{\mathrm{HCl}}$ & $\mathrm{Fe}_{\mathrm{HCl}}$ & Po & $\mathrm{O}_{2 \text { bot }}$ & & \\
\hline $\mathrm{O}_{2}$ & 0.98 & 237.47 & $<0.001$ & $\mathrm{a}$ & $-1.13(\ln )$ & 0.21 & & & -0.15 & -0.26 & & 50.84 & 4 \\
\hline $\ln \left(\mathrm{Si}(\mathrm{OH})_{4}\right)$ & 0.92 & 89.61 & $<0.001$ & $0.34(\ln )$ & a & 0.68 & & & & & -0.15 & -16.21 & 3 \\
\hline $\mathrm{PO}_{4}^{2-}$ & 0.68 & 17.50 & $<0.001$ & $\mathrm{a}$ & $-0.62(\ln )$ & & 1.12 & -1.43 & & & & 206.14 & 3 \\
\hline $\mathrm{NO}_{3}^{-}$ & 0.81 & 32.83 & $<0.001$ & -0.77 & a & & 1.00 & -1.01 & & & & 307.38 & 3 \\
\hline $\mathrm{NO}_{2}^{-}$ & 0.50 & 6.69 & 0.002 & $0.43^{\mathrm{b}}$ & $\mathrm{a}$ & & 1.51 & & & 0.93 & 1.46 & 181.35 & 4 \\
\hline $\ln \left(\mathrm{NH}_{4}^{+}\right)$ & 0.24 & 3.42 & 0.037 & $1.41(\ln )$ & $\mathrm{a}$ & -0.89 & 0.68 & & & & & 72.73 & 3 \\
\hline
\end{tabular}

a Indicates that this short-term parameter was strongly correlated $(R=0.92)$ to the (other) short-term parameter retained in the model.

$\mathrm{b}$ Indicates that the factor was retained, but not significant in the model. 
Table 6. Distance-based linear model of benthic boundary fluxes against environmental drivers determined in the southeastern Beaufort Sea in July/August 2009. Proportion of variance in benthic boundary fluxes explained by environmental variables in stepwise sequential tests following $\mathrm{AIC}_{\mathrm{c}}$ selection criterion. Chl $a=$ sediment chlorophyll $a$ concentration, Phaeo= sediment phaeopigment concentration, $\delta^{13} \mathrm{C}=$ isotopic carbon signature, $\mathrm{Mn}_{\mathrm{HCl}}=$ sediment surface manganese oxides concentration, $\mathrm{O}_{2}$ bot $=$ bottom water oxygen concentration . Prop. is the proportion of variance explained by each single variable; Cumul. is the cumulative proportion of variance explained by multiple variables; res.df $=$ residual degrees of freedom.

\begin{tabular}{lccccccc}
\hline \multicolumn{7}{l}{ Sequential tests for stepwise model (adj. $\left.R^{2}=0.57\right)$} \\
\hline Variable & AIC $_{\mathrm{c}}$ & SS (trace) & Pseudo- $F$ & $P$ & Prop. & Cumul. & res.df \\
\hline $\mathrm{Chl} a$ & 88.69 & 122.14 & 36.72 & $<0.01$ & 0.344 & 0.344 & 70 \\
$\mathrm{Phaeo}$ & 78.39 & 37.04 & 13.05 & $<0.01$ & 0.104 & 0.448 & 69 \\
$\mathrm{O}_{2}$ bot & 74.18 & 16.79 & 6.38 & $<0.01$ & 0.048 & 0.496 & 68 \\
$\delta^{13} \mathrm{C}$ & 66.44 & 23.33 & 10.04 & $<0.01$ & 0.065 & 0.561 & 67 \\
$\mathrm{Mn}$ & 61.47 & 15.11 & 7.09 & $<0.01$ & 0.043 & 0.604 & 66 \\
\hline
\end{tabular}

Percentage of multivariate flux variation explained by individual axes

$\%$ explained variation $\quad \%$ explained variation

out of fitted model out of total variation

\begin{tabular}{lcccc}
\hline Axis & Individual & Cumulative & Individual & Cumulative \\
\hline 1 & 70.51 & 70.51 & 42.59 & 42.59 \\
2 & 20.84 & 91.35 & 12.59 & 55.18 \\
3 & 7.47 & 98.83 & 4.51 & 59.69 \\
4 & 1.16 & 99.99 & 0.7 & 60.39 \\
5 & 0.01 & 100 & 0.01 & 60.4 \\
\hline
\end{tabular}

signature were most strongly correlated with the second dbRDA axis (explaining $20.8 \%$ of fitted flux variation).

\section{Discussion}

In the literature, benthic activity is most often derived from sediment oxygen demand (Graf, 1992; Link et al., 2011; Wenzhöfer and Glud, 2002) and assumed to decrease with increasing depth and distance from the continental source of particles and carbon. However, the heterogeneous pattern of oxygen and nutrient fluxes at the sediment-water interface in the Beaufort Sea emphasizes that benthic remineralisation function is more complex than oxygen fluxes. Here we present for the first time a multiple dataset of benthic boundary fluxes, i.e. for oxygen, silicic acid, phosphate, nitrate, nitrite and ammonium, and their relation with environmental variables in the Canadian Arctic. We discuss their spatial pattern and influences of the environment at different timescales with the aim to estimate dynamics of benthic ecosystem functioning related to variation in the quality and quantity of organic matter export.

\subsection{Ineffectiveness of oxygen flux as proxy for spatial patterns in benthic boundary fluxes.}

In 2009, the spatial pattern of oxygen fluxes (see also Fig. 2 or Table 2) was similar to those reported earlier from the region (2003-2004, 2008) (Darnis et al., 2012;
Link et al., 2011; Renaud et al., 2007b). All those studies reported highest uptake off the Mackenzie Delta and the Cape Bathurst polynya. Oxygen demand at the shallowest sites (690 and 390) was twice the amount reported from 2004 (Renaud et al., 2007b) and half compared to the upwelling year 2008 (Tremblay et al., 2011). Values from other sites were similar for the three studied years. This indicates increased interannual variability of benthic oxygen uptake in the realm of the Mackenzie River plume, whereas the spatial distribution of benthic oxygen uptake as, for example, in the Cape Bathurst polynya is likely controlled by changes in marine primary productivity.

The relatively higher release of silicic acid compared with oxygen uptake in the eastern part of the Beaufort Sea (140, see Fig. 2) matches the different composition of organic matter exported to the seafloor. First, terrestrial input of organic material is high close to the Mackenzie Delta and along the Tuktoyaktuk Peninsula due to the strong influence of the Mackenzie River plume (Macdonald et al., 2004; Magen et al., 2010). This may increase the input of inorganic silicates (Juul-Pedersen et al., 2008), but these are unlikely to be biologically remineralised at the seafloor. Second, primary production in the Cape Bathurst polynya area has a higher diatom contribution (Ardyna et al., 2011) leading to increased silicic shell export (Simpson et al., 2008). In fact, Sampei et al. (2011) identified the Cape Bathurst vicinity as a unique zone in biogenic silicate export out of the euphotic 
zone, with rates roughly one order of magnitude higher than elsewhere across the southeast Beaufort Sea.

Nitrate was replenished at the benthic boundary in deep waters of the slope and in the Cape Bathurst polynya area (sites 235, 345, 110, 140), while sediments on the shallow Mackenzie Shelf (sites 390, 690, 680) act as sink (see Fig. 2). On the shallow Mackenzie Shelf, low oxygen penetration depth $(<1 \mathrm{~cm})$ and a steep gradient in nitrate concentration have been reported, indicating a redox horizon close to the sediment surface (Magen, 2009). Nitrate and nitrite uptake with denitrification processes at the top of the sedimentary column are typically encountered in sediments receiving excess organic matter such as shallow Arctic shelves and continental shelves affected by large river outflow (Chang and Devol, 2009; Hulth et al., 2005; Hyacinthe et al., 2001). Such an input of excess organic matter has also been found during the Malina study (Forest et al., 2013). Nitrate release in the other areas was also consistent with oxygen-saturated degradation. The highest nitrate release in the Cape Bathurst polynya area (site 140) supports the findings of Simpson et al. (2008), who explained excess nutrient concentrations in the deep Amundsen Gulf water with degradation of more available fresh organic matter.

The generally low flux of nitrite reflects its role as an intermediate product of nitrogen compound transformations. Highest uptake rates were linked to sites with high nitrate uptake or low nitrate release (see Fig. 2).

The pattern of ammonium effluxes, which are mainly originated from the anaerobic mineralisation of organic $\mathrm{N}$, is probably explained by the presence/absence of efficient oxidative barriers at the top of the sedimentary column, which contain oxygen and other oxidants such as manganese oxides (Anschutz et al., 2000, 2005; Luther et al., 1997). The highest ammonium effluxes were linked to sites where high organic matter input favours the shallowest oxygen penetration depth and thin manganese oxide rich horizon, e.g. site 390 (Magen, 2009). The upward migration of ammonia to the bottom water probably promoted denitrification processes at the sediment interface at these sites. The within-site heterogeneous patterns of ammonium fluxes (see Fig. 2, Table 2) could be due to physiological responses of different macrofaunal species or densities in the cores (Braeckman et al., 2010), which are not available for our study.

Phosphate uptake from the two shallowest sites near the Mackenzie River delta may again be linked to the low oxygenation, a history of high organic matter input, and to the accumulation at the interface of newly formed reactive iron oxides with high capacity to adsorb phosphate in the area (Hensen et al., 2006; Magen, 2009). Sediment phosphate release can be explained by either a loss of capacity of the sediment to adsorb remobilised phosphate or a production of phosphate via aerobic organic matter mineralisation, or both. Desorption from particulate iron oxide when sediment iron oxide and associated phosphate are exposed to overlying water with lower dissolved $\mathrm{P}$ concentrations relative to pore water (Ruttenberg and Sulak, 2011) can also contribute to phosphate release at the sediment-water interface. The highest phosphate effluxes in the Cape Bathurst polynya (site 140) probably reflected an increased oxic degradation of fresh organic matter, as Davenport et al. (2012) observed on the productive Bering Shelf.

Benthic boundary fluxes of silicic acid, oxygen and phosphate in 2009 were in the range of those reported for the region in 2008 (Darnis et al., 2012). It is noteworthy that phosphate was released from shallow Mackenzie Shelf sediments during the upwelling year 2008 and that notably less silicic acid was remineralised in the Cape Bathurst polynya area in 2008. The increased remineralisation of silicic acid could be explained by the accumulation of excess biogenic silica following vertical export in the highly productive upwelling year of 2008. Phosphate on the other hand is more immediately remineralised from organic matter and the release in 2008 could represent a more short-term reaction to organic matter input from the upwelling year.

Overall, we found that high oxygen demand, nitrate and phosphate uptake prevail in proximity to the Mackenzie outflow, with high ammonium and silicic acid release at the central Mackenzie Delta (site 390), while benthic activity replenishes bottom water with silicic acid, nitrate and phosphate in deeper waters and particularly in the productive Cape Bathurst polynya area (see Fig. 2). Concentrations of nutrients at the onset of our experiments were in the range described for deeper waters in the study region (Simpson et al., 2008). We therefore consider the described spatial pattern of fluxes a realistic estimate. Seasonal changes in nutrient fluxes have been shown in macrofauna nearshore experiments (Braeckman et al., 2010) and can be found in the Bering and Chukchi Sea (Chang and Devol, 2009; Davenport et al., 2012). Here we report nutrient fluxes and mechanisms for the late summer. Considering the seasonal effect in polar benthic systems (Lepore et al., 2007; Link et al., 2011), lower input of fresh organic matter in winter might therefore be accompanied by different oxygen, ammonium and silicic acid fluxes.

When considering all fluxes synchronously, sites can be separated in terms of their remineralisation function, i.e. groups of biogeochemical subregions appear (see also Fig. 3). First, site 390 can be well separated from 690 , and both are different from all other sites. The lower Mackenzie Shelf sites (site 260 and 680) form the next group, which finally can be separated from the Cape Bathurst polynya sites (110 and 140) and the deeper Beaufort slope sites (235 and 345). This spatial pattern is confirmed by lipid biomarker analyses conducted on sediment samples collected from some of our sites (Rontani et al., 2012; Tolosa et al., 2013). For example, particularly high concentrations of autochthonous fresh material derived from diatom production were found at site 390, with 
decreasing concentrations farther north from the Mackenzie Delta (Rontani et al., 2012; Tolosa et al., 2013).

Although sediment oxygen consumption is widely used as a proxy for benthic remineralisation (Glud, 2008; Grebmeier et al., 2006; Holstein and Hensen, 2010; Michaud et al., 2005), our results show that spatial groups of benthic remineralisation are not strictely related to the oxygen flux. In our study, the major differences between the shallow Mackenzie Shelf and all other sites are equally based on different oxygen, nitrate and phosphate fluxes while the eastern Mackenzie Shelf remineralisation differs greatly from the central shelf in silicic acid and ammonium release (see Table 3). Sampling sites in the Cape Bathurst polynya and on the western Mackenzie slope were also distinct from all deeper sites with respect to silicic acid and ammonium release. Clearly, oxygen uptake alone cannot describe the spatial pattern of benthic ecosystem functions in our region. While oxygen uptake is often related to organic matter degradation (e.g. Glud, 2008), further factors influence the quantity and quality of other nutrient remineralisation.

While the influence of terrestrial input seems likely to distinguish the Mackenzie Delta sites from all other sites, an analysis without these sites shows that oxygen is not representative of all fluxes at sites with lower terrestrial input either (Link et al., 2013). Further, the inorganic dissolution of silica depends on $\mathrm{pH}$ or salinity (Loucaides et al., 2012), but other fluxes are less influenced by these environmental factors. Moreover, recent experimental studies have shown that benthic fluxes other than oxygen, e.g. silicic acid or ammonium, change as a result of different organic matter input (Callier et al., 2008; Richard et al., 2007). Such effects have been related to particular species present in treatments, which influence microbial activity (Michaud et al., 2009; Robert et al., 2013). For example, Michaud et al. (2009) have demonstrated differences in benthic fluxes when sediments contained either the polychaete Alitta virens, the bivalves Mya arenaria or Macoma balthica, or a combination of these species, always keeping the total volume of macrofaunal organisms constant. Although we can assume different benthic faunal composition on the Mackenzie Shelf, slope and Cape Bathurst area (Conlan et al., 2008), we do not know how each Beaufort Sea species influences each flux, and even less how they interact with the benthic microbial community. Hence, our results suggest that multiple fluxes need to be considered when the spatial variability of benthic ecosystem functioning in terms of nutrient replenishment is evaluated - independent of which factors are mainly controlling the spatial pattern of nutrient remineralisation.

\subsection{Timescales and distinct environmental forcings on different biogeochemical fluxes}

The heterogeneous spatial pattern of benthic boundary fluxes announces the complexity of different factor combinations determining each single flux. Our results of multiple regression analysis show that different subsets of environmental factors can explain spatial variation of different single fluxes, to a surprisingly high part (up to $98 \%)$.

While short-term environmental conditions do always explain part of the variation, a large sinking particle flux and an associated increased concentration of sediment $\mathrm{Chl} a$ most strongly increase oxygen uptake and ammonium release. Observational as well as experimental studies have already demonstrated rapid response of benthic communities to food input (Pfannkuche, 1993; Sun et al., 2007). Ammonium release has been linked to oxic degradation of high quality organic matter by bacterial or faunal communities in shallow and Arctic sediments (Rysgaard et al., 2004). The low explicative power of the best model for ammonium fluxes $(24 \%)$ indicates that other factors not identified here were playing a substantial role in driving its spatial variability. The faunal composition, which has important effects on ammonium release by sediment oxygenation and bioturbation, might be one of these lacking measurements (Braeckman et al., 2010; Laverock et al., 2011; Piot et al., 2013). But also environmental parameters of long-term variability, such as pore water $\mathrm{pH}$ or sediment mineralogy are assumed to influence ammonium fluxes in the sediments (Gao et al., 2012; Müller, 1977). Such data is unavailable for our study, but including pore water $\mathrm{pH}$ in statistical models in the future may yield higher explicative power for ammonium fluxes.

Environmental parameters of long-term variability (e.g. $\mathrm{Mn}_{\mathrm{HCl}}$, porosity, bottom water oxygen) are powerful predictors of phosphate, nitrate and nitrite fluxes, when the origin of organic matter (terrigenous vs. marine) is simultaneously considered. This combination may reflect the long-term influence of terrigenous matter sedimentation from the Mackenzie River (Macdonald et al., 2004). The long-term input of organic matter, porosity and surrounding bottom water oxygen concentration limit the depth of the sediment oxic layer. Also, the manganese oxide rich horizon with higher surficial $\mathrm{Mn}_{\mathrm{HCl}}$ indicates degradation of organic matter under suboxic conditions during the last decades, which is capable of producing an upward dissolved manganese flux that precipitates at the sediment interface (Aller, 1988). These redox conditions also control denitrification and phosphate binding processes and seem to be more important for $\mathrm{NO}_{\mathrm{x}}$ and phosphate release than the input of fresh marine matter.

We would have assumed that silicic acid release was positively related to Chl $a$ and phaeopigment concentration, since we considered sediment pigments a proxy of organic detritus input to the seafloor. Following dissolution kinetics, silicic acid release supposedly increases with silicate input (Tréguer et al., 1995), and we assumed that more organic detritus sinking to the seafloor implies a high silicate input to sediments. However, phaeopigments at the seafloor reflect both silicic and non-silicic organic detritus. Thus, sediments 
containing increased concentrations of phaeopigments can be the consequence of both past and present diatom-poor primary production at these locations, likely affected by low pelagic nitrate availability, and would therefore not lead to increased silicic acid release. Moreover, if high phaeopigment concentration in sediments results from faecal pellets, dissolution of biogenic silicates is most likely hindered by the compaction or membranes of faecal pellets (Loucaides et al., 2012). Recently, Holstein and Hensen (2010) have also demonstrated the importance of bacterial silicate release in oxygenated sediments. Bacterial biomarker concentrations were more abundant in sediments with higher fresh labile matter ( $\mathrm{Chl} a$ ) compared to the total input of organic matter (Tolosa et al., 2013). These observations would further explain why an increase in silicic acid release was found in association with increasing Chl $a$ and decreasing phaeopigments in our study.

In summary, while short-term factors such as fresh marine matter enhance the oxic degradation and nutrient replenishment, long-term factors reflecting decadal-scale input of organic matter dominates the remineralisation of $\mathrm{NO}_{\mathrm{x}}$ and phosphate on the southeastern Beaufort Shelf. The insight from our results may facilitate modelling of single nutrient biogeochemical cycles by including broader environmental parameters. But from an ecological view, a simplified statistical model predicting all different fluxes with the same environmental parameters is more practical.

\subsection{Statistical modelling of benthic remineralisation using environmental parameters}

Despite the differences in environmental factors explaining each single flux (see above), the majority $(57 \%)$ of spatial variation in multiple benthic remineralisation function can be explained by a subset of the following five environmental factors: sediment surface $\mathrm{Chl} a$ (also a proxy for sinking particle fluxes), phaeopigment and manganese oxide concentration, $\delta^{13} \mathrm{C}$ signature and bottom water oxygen concentration. The similarity of the dbRDA plot and the PCA plot (see Figs. 3 and 4) shows that the environmental variables explain benthic flux variation fairly well, with a little less congruence for the shallow Mackenzie sites (Anderson et al., 2008). The input of fresh organic matter $(\mathrm{Chl} a)$ alone can explain a third of the spatial variation, separating the deeper sites from the shelf and shallow sites, particularly site 390 (see Fig. 4). This stresses the importance of short-term parameters for the estimation of nutrient release from Arctic sediments. The quality of organic matter has repeatedly been related to benthic oxygen demand (Link et al., 2011; Renaud et al., 2007a), infaunal diversity (Conlan et al., 2008) and bacterial activity (Rontani et al., 2012) in the southeastern Beaufort Sea. Assuming the importance of biological activity for phosphate (Davenport et al., 2012), nitrogen derivates (Braeckman et al., 2010; Chang and Devol, 2009) and silicic acid (Holstein and Hensen,
2010) release, fresh organic matter with high Chl $a$ content provides energy for bacterial degradation. It also stimulates benthic ecosystem functioning in terms of biological activity of macrofauna, which additionally enhances nutrient release.

The greater marine fraction and phaeopigment content in organic matter input are the primary determinants of the different benthic boundary fluxes in the Cape Bathurst polynya area when compared with fluxes close to the Mackenzie Delta (see Fig. 4). It is clear that locations influenced by the Mackenzie River plume, which feeds a high sedimentation flux of terrigenous particulate matter (JuulPedersen et al., 2010; Magen et al., 2010), will show a distinctly different benthic ecosystem functioning.

Finally, the influence of bottom water oxygenation and manganese oxides along the shelf-basin transect north of station 390 (see Fig. 4) demonstrates how long-term environmental factors drive spatial variation in benthic boundary fluxes. Both these factors relate to mostly geochemical processes in the sediments (Gobeil et al., 2001), and may therefore describe an underlying low-frequency variation, on top of which short-term environmental factors further modify benthic fluxes.

About $40 \%$ of the total variation in benthic remineralisation function could not be explained by any of the environmental conditions included in the analysis. The most likely missing factor is faunal or bacterial abundance and composition in the analysed sediment cores. An increasing number of studies report the key role of benthic species for benthic boundary fluxes, particularly through their bioturbation or bioirrigation (Davenport et al., 2012; Kristensen et al., 2012). Benthic fauna thus can locally directly enhance nutrient remineralisation or indirectly by modifying bacterial abundance (Michaud et al., 2009; Piot et al., 2013).

It is noteworthy that sediment porosity, a major parameter used to calculate diffusive fluxes across the sediment water interface (e.g. Hensen et al., 2006), does not play a significant role in our analysis. Again, this emphasizes the role of biological processes for spatial variation in benthic ecosystem functioning in the southeastern Beaufort Sea.

\section{Conclusions}

In this study we aim to find environmental factors to predict benthic ecosystem functioning on polar shelves. Our results provide some of the few data on biogeochemical fluxes across the benthic boundary and insights on their spatial gradients and driving factors on Canadian Arctic shelves. We report that in summer the sediments of the southeastern Beaufort Sea are usually a source of silicic acid, while the Mackenzie Delta is a region of nitrate and phosphate uptake and more marine-influenced areas are areas of nitrate release. Environmental factors varying on a short-term scale are the dominant drivers of benthic remineralisation function 
and indicate that benthic remineralisation rates in terms of quantity will quite rapidly respond to climate changes. On a longer timescale, if terrigenous matter sedimentation from the Mackenzie River and water temperatures increase with climate change, we can expect a decrease in oxygen concentration of coastal bottom waters and sediments, with the latter shifting from nutrient sources to sinks. Contrary to present practice, oxygen flux does not adequately represent the spatial variation in other nutrient sink-source dynamics. When evaluating the importance of benthic processes for the pelagic system, we therefore suggest to use qualitative models to predict spatial variation of multivariate benthic remineralisation from environmental parameters (these may be relative values). These could be calibrated to absolute expected values with easily measurable fluxes (e.g. oxygen). Overall, our results emphasize the importance of biologically mediated degradation interacting with geochemical processes. Including more specific markers of fresh biologically degradable matter and faunal composition data in benthic boundary flux models should further enhance the predictive power of biological ecosystem models. Improving our understanding of the balance between benthic and pelagic systems, and their feedbacks, will become more important in the face of climate and anthropogenic-induced changes.

Acknowledgements. We would like to thank the CCGS Amundsen officers and crew, Malina chief scientist M. Babin, and all scientists and technicians for their support on board. Special thanks go to J. Gagnon and J.-E. Tremblay for nutrient analyses. We are grateful for the help of V. Galy in the laboratory. We also thank Jens Holtvoeth for his valuable comments on our manuscript. Financial support was received from the National Science and Engineering Research Council (NSERC) Strategic Canadian Healthy Oceans Network (CHONe) and ArcticNet. Partial funding was provided by the Fonds québécois de la recherche sur la nature et les technologies (FQRNT) and Québec-Océan for H. Link, and the Canadian Research Chair and Institutional UQAR funding for G. Chaillou. This study was conducted as part of the Malina Scientific Program funded by ANR (Agence nationale de la recherche), INSU-CNRS (Institut national des sciences de l'univers - Centre national de la recherche scientifique), CNES (Centre national d'études spatiales) and ESA (European Space Agency).

Edited by: C. Woulds

\section{References}

ACIA: Arctic Climate Impact Assessment (ACIA), Cambridge, UK, 1046, 2004.

Akaike, H.: A new look at the Bayes procedure, Biometrika, 65, 53-59, 1978.

Aller, R. C.: Benthic fauna and biogeochemical processes in marine sediments: The role of burrow structures, in: Nitrogen cycling in coastal marine environments, edited by: Blackburn, T. H. and Sørensen, J., John Wiley, 301-338, 1988.
Anderson, M. J., Gorley, R. N., and Clarke, K. R.: PERMANOVA+ for PRIMER: guide to software and statistical methods, PRIMER-E Ltd., Plymouth, UK, 2008.

Anschutz, H., Eisen, O., Rack, W., and Scheinert, M.: Periodic surface features in coastal East Antarctica, Geophys. Res. Lett., 33, L22501, doi:10.1029/2006g1027871, 2006.

Anschutz, P., Sundby, B., Lefrancois, L., Luther, G. W., and Mucci, A.: Interactions between metal oxides and species of nitrogen and iodine in bioturbated marine sediments, Geochim. Cosmochim. Ac., 64, 2751-2763, doi:10.1016/s00167037(00)00400-2, 2000.

Anschutz, P., Dedieu, K., Desmazes, F., and Chaillou, G.: Speciation, oxidation state, and reactivity of particulate manganese in marine sediments, Chem. Geol., 218, 265-279, doi:10.1016/j.chemgeo.2005.01.008, 2005.

Ardyna, M., Gosselin, M., Michel, C., Poulin, M., and Tremblay, J. E.: Environmental forcing of phytoplankton community structure and function in the Canadian High Arctic: contrasting oligotrophic and eutrophic regions, Mar. Ecol.-Prog. Ser., 442, 37-57, doi:10.3354/meps09378, 2011.

Arrigo, K. R. and van Dijken, G. L.: Annual cycles of sea ice and phytoplankton in Cape Bathurst polynya, southeastern Beaufort Sea, Canadian Arctic, Geophys. Res. Lett., 31, L08304, doi:10.1029/2003g1018978, 2004.

Barber, D., Asplin, M., Papakyriakou, T., Miller, L., Else, B., Iacozza, J., Mundy, C., Gosslin, M., Asselin, N., Ferguson, S., Lukovich, J., Stern, G., Gaden, A., Pućko, M., Geilfus, N. X., and Wang, F.: Consequences of change and variability in sea ice on marine ecosystem and biogeochemical processes during the 2007-2008 Canadian International Polar Year program, Climatic Change, 115, 135-159, doi:10.1007/s10584-012-0482-9, 2012.

Bélanger, S., Xie, H. X., Krotkov, N., Larouche, P., Vincent, W. F., and Babin, M.: Photomineralization of terrigenous dissolved organic matter in Arctic coastal waters from 1979 to 2003: Interannual variability and implications of climate change, Global Biogeochem. Cy., 20, GB4005, doi:10.1029/2006gb002708, 2006.

Benner, R., Benitez-Nelson, B., Kaiser, K., and Amon, R. M. W.: Export of young terrigenous dissolved organic carbon from rivers to the Arctic Ocean, Geophys. Res. Lett., 31, L05305, doi:10.1029/2003g1019251, 2004.

Berner, R. A.: Early Diagenesis. A theoretical approach, Princeton University Press, 1980.

Braeckman, U., Provoost, P., Gribsholt, B., Van Gansbeke, D., Middelburg, J. J., Soetaert, K., Vincx, M., and Vanaverbeke, J.: Role of macrofauna functional traits and density in biogeochemical fluxes and bioturbation, Mar. Ecol.-Prog. Ser., 399, 173-186, doi:10.3354/meps08336, 2010.

Bringué, M. and Rochon, A.: Late Holocene paleoceanography and climate variability over the Mackenzie Slope (Beaufort Sea, Canadian Arctic), Mar. Geol., 291, 83-96, doi:10.1016/j.margeo.2011.11.004, 2012.

Callier, M. D., McKindsey, C. W., and Desrosiers, G.: Evaluation of indicators used to detect mussel farm influence on the benthos: two case studies in the Magdalen Islands, Eastern Canada, Aquaculture, 278, 77-88, 2008.

Canfield, D. E., Thamdrup, B., and Hansen, J. W.: The anaerobic degradation of organic matter in Danish coastal sediments iron reduction, manganese reduction, and sulfate reduction, 
Geochim. Cosmochim. Ac., 57, 3867-3883, doi:10.1016/00167037(93)90340-3, 1993.

Chan, F., Barth, J., Lubchenco, J., Kirincich, J., Weeks, A., Peterson, H., Mengl, W. T., and Chan, B. A.: Emergence of anoxia in the California Current Large Marine Ecosystem, Science, 319, p. 920, 2008.

Chang, B. X. and Devol, A. H.: Seasonal and spatial patterns of sedimentary denitrification rates in the Chukchi sea, Deep Sea Res. Pt. II, 56, 1339-1350, 2009.

Clarke, K. R. and Gorley, R. N.: PRIMER v6: User manual/tutorial, PRIMER-E Ltd., Plymouth, UK, 192 pp., 2006.

Conlan, K., Aitken, A., Hendrycks, E., McClelland, C., and Melling, H.: Distribution patterns of Canadian Beaufort Shelf macrobenthos, J. Marine Syst., 74, 864-886, doi:10.1016/j.jmarsys.2007.10.002, 2008.

Darnis, G., Robert, D., Pomerleau, C., Link, H., Archambault, P., Nelson, R., Geoffroy, M., Tremblay, J.-É., Lovejoy, C., Ferguson, S., Hunt, B., and Fortier, L.: Current state and trends in Canadian Arctic marine ecosystems: II. Heterotrophic food web, pelagicbenthic coupling, and biodiversity, Climatic Change, 115, 179205, doi:10.1007/s10584-012-0483-8, 2012.

Davenport, E. S., Shull, D. H., and Devol, A. H.: Roles of sorption and tube-dwelling benthos in the cycling of phosphorus in Bering Sea sediments, Deep Sea Res. Pt. II, 65-70, 163-172, doi:10.1016/j.dsr2.2012.02.004, 2012.

Durantou, L., Rochon, A., Ledu, D., Massé, G., Schmidt, S., and Babin, M.: Quantitative reconstruction of sea-surface conditions over the last $150 \mathrm{yr}$ in the Beaufort Sea based on dinoflagellate cyst assemblages: the role of large-scale atmospheric circulation patterns, Biogeosciences, 9, 5391-5406, doi:10.5194/bg-9-53912012, 2012.

Ebenhöh, W., Kohlmeier, C., and Radford, P. J.: The benthic biological submodel in the European regional seas ecosystem model, Neth. J. Sea Res., 33, 423-452, 1995.

Forest, A., Sampei, M., Hattori, H., Makabe, R., Sasaki, H., Fukuchi, M., Wassmann, P., and Fortier, L.: Particulate organic carbon fluxes on the slope of the Mackenzie Shelf (Beaufort Sea): Physical and biological forcing of shelf-basin exchanges, J. Marine Syst., 68, 39-54, doi:10.1016/j.jmarsys.2006.10.008, 2007.

Forest, A., Bélanger, S., Sampei, M., Sasaki, H., C., Lalande, C., and Fortier, L.: Three-year assessment of particulate organic carbon fluxes in Amundsen Gulf (Beaufort Sea): Satellite observations and sediment trap measurements, Deep-Sea Res. Pt. I, 57, 125-142, doi:10.1016/j.dsr.2009.10.002, 2010.

Forest, A., Tremblay, J.-É., Gratton, Y., Martin, J., Gagnon, J., Darnis, G., Sampei, M., Fortier, L., Ardyna, M., Gosselin, M., Hattori, H., Nguyen, D., Maranger, R., Vaqué, D., Marrasé, C., Pedrós-Alió, C., Sallon, A., Michel, C., Kellogg, C., Deming, J., Shadwick, E., Thomas, H., Link, H., Archambault, P., and Piepenburg, D.: Biogenic carbon flows through the planktonic food web of the Amundsen Gulf (Arctic Ocean): A synthesis of field measurements and inverse modeling analyses, Prog. Oceanogr., 91, 410-436, doi:10.1016/j.pocean.2011.05.002, 2011.

Forest, A., Babin, M., Stemmann, L., Picheral, M., Sampei, M., Fortier, L., Gratton, Y., Bélanger, S., Devred, E., Sahlin, J., Doxaran, D., Joux, F., Ortega-Retuerta, E., Martín, J., Jeffrey, W. H., Gasser, B., and Carlos Miquel, J.: Ecosystem function and particle flux dynamics across the Mackenzie Shelf (Beaufort Sea, Arctic Ocean): an integrative analysis of spatial variability and biophysical forcings, Biogeosciences, 10, 28332866, doi:10.5194/bg-10-2833-2013, 2013.

Froelich, P. N., Klinkhammer, G. P., Bender, M. L., Luedtke, N. A., Heath, G. R., Cullen, D., Dauphin, P., Hammond, D., Hartman, B., and Maynard, V.: Early oxidation of organic-matter in pelagic sediments of the eastern equatorial atlantic - suboxic diagenesis, Geochim. Cosmochim. Ac., 43, 1075-1090, 1979.

Fukasawa, M., Freeland, H., Perkin, R., Watanabe, T., Uchida, H., and Nishina, A.: Bottom water warming in the North Pacific Ocean, Nature, 427, 825-827, 2004.

Galley, R. J., Key, E., Barber, D. G., Hwang, B. J., and Ehn, J. K.: Spatial and temporal variability of sea ice in the southern Beaufort Sea and Amundsen Gulf: 1980-2004, J. Geophys. Res.Oceans, 113, C05s95, doi:10.1029/2007jc004553, 2008.

Gao, Y., Cornwell, J. C., Stoecker, D. K., and Owens, M. S.: Effects of cyanobacterial-driven $\mathrm{pH}$ increases on sediment nutrient fluxes and coupled nitrification-denitrification in a shallow fresh water estuary, Biogeosciences, 9, 2697-2710, doi:10.5194/bg-92697-2012, 2012.

Gilbert, D., Sundby, B., Gobeil, C. and Mucci, A.: A seventytwo-year record of diminishing deep-water oxygen in the St. Lawrence estuary: The northwest Atlantic connection, Limnol. Oceanogr., 50, 1654-1666, 2005.

Gilbert, D., Rabalais, N. N., Díaz, R. J., and Zhang, J.: Evidence for greater oxygen decline rates in the coastal ocean than in the open ocean, Biogeosciences, 7, 2283-2296, doi:10.5194/bg-72283-2010, 2010.

Glud, R. N.: Oxygen dynamics of marine sediments, Mar. Biol. Res., 4, 243-289, doi:10.1080/17451000801888726, 2008.

Gobeil, C., Sundby, B., Macdonald, R. W., and Smith, J. N.: Recent change in organic carbon flux to Arctic Ocean deep basins: Evidence from acid volatile sulfide, manganese and rhenium discord in sediments, Geophys. Res. Lett., 28, 1743-1746, 2001.

Godbold, J. A. and Solan, M.: Relative importance of biodiversity and the abiotic environment in mediating an ecosystem process, Mar. Ecol.-Prog. Ser., 396, 273-282, doi:10.3354/meps08401, 2009.

Goni, M. A., Yunker, M. B., Macdonald, R. W., and Eglinton, T. I.: The supply and preservation of ancient and modem components of organic carbon in the Canadian Beaufort Shelf of the Arctic Ocean, Mar. Chem., 93, 53-73, doi:10.1016/j.marchem.2004.08.001, 2005.

Graf, G.: Benthic-Pelagic Coupling - A Benthic View, Oceanogr. Mar. Biol., 30, 149-190, 1992.

Grasshoff, K., Kremling, K., and Ehrhardt, M.: Methods of Seawater Analysis, in, Wiley-VCH, Weinheim, New York, 159228, 1999.

Grebmeier, J. M., Cooper, L. W., Feder, H. M., and Sirenko, B. I.: Ecosystem dynamics of the Pacific-influenced Northern Bering and Chukchi Seas in the Amerasian Arctic, Prog. Oceanogr., 71, 331-361, 2006.

Guidi, L., Jackson, G. A., Stemmann, L., Miquel, J. C., Picheral, M., and Gorsky, G.: Relationship between particle size distribution and flux in the mesopelagic zone, Deep Sea Res. Pt. I, 55, 13641374, doi:10.1016/j.dsr.2008.05.014, 2008.

Hall, P. O. J., Anderson, L. G., Vanderloeff, M. M. R., Sundby, B., and Westerlund, S. F. G.: Oxygen uptake kinetics in the benthic 
boundary layer, Limnol. Oceanogr., 34, 734-746, 1989.

Hensen, C., Zabel, M., and Schulz, H.: Benthic Cycling of Oxygen, Nitrogen and Phosphorus, in: Marine Geochemistry, edited by: Schulz, H. D. and Zabel, M., Springer Berlin Heidelberg, 207240, 2006

Holmes, R. M., Aminot, A., Kerouel, R., Hooker, B. A., and Peterson, B. J.: A simple and precise method for measuring ammonium in marine and freshwater ecosystems, Can. J. Fish. Aquat. Sci., 56, 1801-1808, 1999.

Holstein, J. and Hensen, C.: Microbial mediation of benthic biogenic silica dissolution, Geo-Mar. Lett., 30, 477-492, doi:10.1007/s00367-009-0181-3, 2010.

Hulth, S., Aller, R. C., Canfield, D. E., Dalsgaard, T., Engstrom, P., Gilbert, F., Sundback, K., and Thamdrup, B.: Nitrogen removal in marine environments: recent findings and future research challenges, Mar. Chem., 94, 125-145, doi:10.1016/j.marchem.2004.07.013, 2005.

Hyacinthe, C., Anschutz, P., Carbonel, P., Jouanneau, J. M., and Jorissen, F. J.: Early diagenetic processes in the muddy sediments of the Bay of Biscay, Mar. Geol., 177, 111-128, doi:10.1016/s0025-3227(01)00127-x, 2001.

Juul-Pedersen, T., Michel, C., and Gosselin, M.: Influence of the Mackenzie River plume on the sinking export of particulate material on the shelf, J. Marine Syst., 74, 810-824, doi:10.1016/j.jmarsys.2008.02.001, 2008.

Juul-Pedersen, T., Michel, C., and Gosselin, M.: Sinking export of particulate organic material from the euphotic zone in the eastern Beaufort Sea, Mar. Ecol.-Prog. Ser., 410, 55-70, doi:10.3354/meps08608, 2010.

Katsev, S., Sundby, B., and Mucci, A.: Modeling vertical excursions of the redox boundary in sediments: Application to deep basins of the Arctic Ocean, Limnol. Oceanogr., 51, 1581-1593, 2006.

Kristensen, E., Penha-Lopes, G., Delefosse, M., Valdemarsen, T., Quintana, C. O., and Banta, G. T.: What is bioturbation? The need for a precise definition for fauna in aquatic sciences, Mar. Ecol.-Prog. Ser., 446, 285-302, doi:10.3354/meps09506, 2012.

Lalande, C., Forest, A., Barber, D. G., Gratton, Y., and Fortier, L.: Variability in the annual cycle of vertical particulate organic carbon export on Arctic shelves: Contrasting the Laptev Sea, Northern Baffin Bay and the Beaufort Sea, Cont. Shelf Res., 29, 2157-2165, 2009.

Laverock, B., Gilbert, J. A., Tait, K., Osborn, A. M., and Widdicombe, S.: Bioturbation: impact on the marine nitrogen cycle, Biochem. Soc. Trans., 39, 315-320, 10.1042/bst0390315, 2011

Lefort, S., Mucci, A., and Sundby, B.: Sediment Response to 25 Years of Persistent Hypoxia, Aquat. Geochem., 18, 461-474, doi:10.1007/s10498-012-9173-4, 2012.

Lepore, K., Moran, S. B., Grebmeier, J. M., Cooper, L. W., Lalande, C., Maslowski, W., Hill, V., Bates, N. R., Hansell, D. A., Mathis, J. T., and Kelly, R. P.: Seasonal and interannual changes in particulate organic carbon export and deposition in the Chukchi Sea, J. Geophys. Res.-Oceans, 112, C10024, doi:10.1029/2006jc003555, 2007.

Link, H., Archambault, P., Tamelander, T., Renaud, P. E., and Piepenburg, D.: Spring-to-summer changes and regional variability of benthic processes in the western Canadian Arctic, Polar Biol., 34, 2025-2038, doi:10.1007/s00300-011-1046-6, 2011.
Link, H., Chaillou, G., Forest, A., Piepenburg, D., and Archambault, P.: Interactive comment on "Multivariate benthic ecosystem functioning in the Arctic - benthic fluxes explained by environmental parameters in the southeastern Beaufort Sea", Biogeosciences Discuss., http://www.biogeosciences-discuss. net/9/C9453/2013/bgd-9-C9453-2013-supplement.pdf, 2013.

Loucaides, S., Cappellen, P., Roubeix, V., Moriceau, B., and Ragueneau, O.: Controls on the Recycling and Preservation of Biogenic Silica from Biomineralization to Burial, Silicon, 4, 722, doi:10.1007/s12633-011-9092-9, 2012.

Luther, G. W., Sundby, B., Lewis, B. L., Brendel, P. J., and Silverberg, N.: Interactions of manganese with the nitrogen cycle: Alternative pathways to dinitrogen, Geochim. Cosmochim. Ac., 61, 4043-4052, doi:10.1016/s0016-7037(97)00239-1, 1997.

Macdonald, R. W., Naidu, A. S., Yunker, M. B., and Gobeil, C.: The Beaufort Sea: Distribution, Sources, Fluxes, and Burial Rates of Organic Carbon, in: The Organic Carbon Cycle in the Arctic Ocean, edited by: Stein, R. and Macdonald, R. W., Springer, Berlin Heidelberg, Germany, 177-192, 2004.

Magen, C.: Origin, Sedimentation and Diagenesis of Organic Matter in Coastal Sediments of the Southern Beaufort Sea Region, Canadian Arctic, PhD, McGill University, 2009.

Magen, C., Chaillou, G., Crowe, S. A., Mucci, A., Sundby, B., Gao, A. G., Makabe, R., and Sasaki, H.: Origin and fate of particulate organic matter in the southern Beaufort Sea - Amundsen Gulf region, Canadian Arctic, Estuar. Coast. Shelf S., 86, 31-41, doi:10.1016/j.ecss.2009.09.009, 2010.

McArdle, B. H. and Anderson, M. J.: Fitting multivariate models to community data: a comment on distance-based redundancy analysis, Ecology, 82, 290-297, 2001.

Michaud, E., Desrosiers, G., Mermillod-Blondin, F., Sundby, B., and Stora, G.: The functional group approach to bioturbation: The effects of biodiffusers and gallery-diffusers of the Macoma balthica community on sediment oxygen uptake, J. Exp. Mar. Biol. Ecol., 326, 77-88, 2005.

Michaud, E., Desrosiers, G., Aller, R. C., Mermillod-Blondin, F., Sundby, B., and Stora, G.: Spatial interactions in the Macoma balthica community control biogeochemical fluxes at the sediment-water interface and microbial abundances, J. Mar. Res., 67, 43-70, 2009.

Morata, N., Renaud, P. E., Brugel, S., Hobson, K. A., and Johnson, B. J.: Spatial and seasonal variations in the pelagicbenthic coupling of the southeastern Beaufort Sea revealed by sedimentary biomarkers, Mar. Ecol.-Prog. Ser., 371, 47-63, doi:10.3354/meps07677, 2008.

Müller P. J.: C/N ratios in Pacifie deep-sea sediments: effect of inorganic ammonium and organic nitrogen compounds sorbed by clays, Geochim. Cosmochim. Ac., 41, 765-776, 1977.

Mundy, C. J., Gosselin, M., Ehn, J., Gratton, Y., Rossnagel, A., Barber, D. G., Martin, J., Tremblay, J. E., Palmer, M., Arrigo, K. R., Darnis, G., Fortier, L., Else, B., and Papakyriakou, T.: Contribution of under-ice primary production to an ice-edge upwelling phytoplankton bloom in the Canadian Beaufort Sea, Geophys. Res. Lett., 36, L17601 doi:10.1029/2009g1038837, 2009.

Naidu, A. S., Cooper, L. W., Finney, B. P., Macdonald, R. W., Alexander, C., and Semiletov, I. P.: Organic carbon isotope ratios (delta C-13) of Arctic Amerasian Continental shelf sediments, Int. J. Earth Sci., 89, 522-532, doi:10.1007/s005310000121, 
2000.

O’Brien, M. C., Macdonald, R. W., Melling, H., and Iseki, K.: Particle fluxes and geochemistry on the Canadian Beaufort Shelf: Implications for sediment transport and deposition, Cont. Shelf Res., 26, 41-81, 2006.

Ortega-Retuerta, E., Jeffrey, W. H., Babin, M., Bélanger, S., Benner, R., Marie, D., Matsuoka, A., Raimbault, P., and Joux, F.: Carbon fluxes in the Canadian Arctic: patterns and drivers of bacterial abundance, production and respiration on the Beaufort Sea margin, Biogeosciences, 9, 3679-3692, doi:10.5194/bg-9-36792012, 2012.

Pfannkuche, O.: Benthic response to the sedimentation of particulate organic matter at the Biotrans station, 47-degrees-N, 20-degrees-W, Deep-Sea Res. Pt. II, 40, 135-149, 1993.

Picheral, M., Guidi, L., Stemmann, L., Karl, D. M., Iddaoud, G., and Gorsky, G.: The Underwater Vision Profiler 5: An advanced instrument for high spatial resolution studies of particle size spectra and zooplankton, Limnol. Oceanogr.-Meth., 8, 462-473, 2010.

Piot, A., Nozais, C., and Archambault, P.: Meiofauna affect the macrobenthic biodiversity-ecosystem functioning relationship, Oikos, in press, 2013.

Quinn, G. and Keough, M.: Experimental design and data analysis for biologists, Cambridge University Press, Cambridge, UK, 537 pp., 2002.

Rabalais, N. N., Turner, R. E., Diaz, R. J., and Justic , D.: Global change and eutrophication of coastal waters, ICES J. Mar. Sci., 66, 1528-1537, 2009.

Rachold, V., Eicken, H., Gordeev, V. V., Grigoriev, M. N., Hubberten, H.-W., Lisitzin, A. P., Shevchenko, V. P., and Schirrmeister, L.: Modern terrigenous organic carbon input to the Arctic Ocean, in: The Organic Carbon Cycle in the Arctic Ocean, edited by: Stein, R. and Macdonald, R. W., Springer, Berlin Heidelberg, Germany, 33-55, 2004.

Renaud, P. E., Morata, N., Ambrose, W. G., Bowie, J. J., and Chiuchiolo, A.: Carbon cycling by seafloor communities on the eastern Beaufort Sea shelf, J. Exp. Mar. Biol. Ecol., 349, 248260, 2007a.

Renaud, P. E., Riedel, A., Michel, C., Morata, N., Gosselin, M., Juul-Pedersen, T., and Chiuchiolo, A.: Seasonal variation in benthic community oxygen demand: A response to an ice algal bloom in the Beaufort Sea, Canadian Arctic?, J. Marine Syst., 67, 1-12, 2007b.

Riaux-Gobin, C. and Klein, B.: Microphytobenthic Biomass Measurement Using HPLC and Conventional Pigment Analysis, in: Handbook of methods in aquatic microbial ecology, edited by: Kemp, P., Sherr, B., Sherr, E., and Cole, J., Lewis Publishers, Boca Raton, 369-376, 1993.

Richard, M., Archambault, P., Thouzeau, G., and Desrosiers, G.: Summer influence of 1 and 2 yr old mussel cultures on benthic fluxes in Grande-Entrée lagoon, Îles-de-la-Madeleine (Québec, Canada), Mar. Ecol.-Prog. Ser., 338, 131-143, 2007.

Richerol, T., Rochon, A., Blasco, S., Scott, D. B., Schell, T. M., and Bennett, R. J.: Distribution of dinoflagellate cysts in surface sediments of the Mackenzie Shelf and Amundsen Gulf, Beaufort Sea (Canada), J. Marine Syst., 74, 825-839, doi:10.1016/j.jmarsys.2007.11.003, 2008.

Robert, P., McKindsey, C. W., Chaillou, G., and Archambault, P.: Dose-dependent response of a benthic system to biodeposition from suspended blue mussel (Mytilus edulis) culture, Mar. Pollut. Bull., 66, 92-104, doi:10.1016/j.marpolbul.2012.11.003, 2013.

Rontani, J.-F., Charriere, B., Petit, M., Vaultier, F., Heipieper, H. J., Link, H., Chaillou, G., and Sempéré, R.: Degradation state of organic matter in surface sediments from the Southern Beaufort Sea: a lipid approach, Biogeosciences, 9, 3513-3530, doi:10.5194/bg-9-3513-2012, 2012.

Ruttenberg, K. C. and Sulak, D. J.: Sorption and desorption of dissolved organic phosphorus onto iron (oxyhydr)oxides in seawater, Geochim. Cosmochim. Ac., 75, 4095-4112, 2011.

Rysgaard, S., Thamdrup, B., Risgaard-Petersen, N., Fossing, H., Berg, P., Christensen, P. B., and Dalsgaard, T.: Seasonal carbon and nutrient mineralization in a high-Arctic coastal marine sediment, Young Sound, Northeast Greenland, Mar. Ecol.-Prog. Ser., 175, 261-276, doi:10.3354/meps 175261, 1998.

Rysgaard, S., Glud, R. N., Risgaard-Petersen, N., and Dalsgaard, T.: Denitrification and anammox activity in Arctic marine sediments, Limnol. Oceanogr., 49, 1493-1502, 2004.

Sakshaug, E.: Primary and Secondary Production in the Arctic Seas, in: The Organic Carbon Cycle in the Arctic Ocean, edited by: Stein, R. and Macdonald, R. W., Springer, Berlin Heidelberg, Germany, 57-82, 2004.

Sallon, A., Michel, C., and Gosselin, M.: Summertime primary production and carbon export in the southeastern Beaufort Sea during the low ice year of 2008, Polar Biol., 34, 1989-2005, doi:10.1007/s00300-011-1055-5, 2011.

Sampei, M., Sasaki, H., Makabe, R., Forest, A., Hattori, H., Tremblay, J.-É., Gratton, Y., Fukuchi, M., and Fortier, L.: Production and retention of biogenic matter in the southeast Beaufort Sea during 2003-2004: insights from annual vertical particle fluxes of organic carbon and biogenic silica, Polar Biol., 34, 501-511, doi:10.1007/s00300-010-0904-y, 2011.

Schmid, B., Balvanera, P., Cardinale, B., Godbold, J., Pfisterer, A. B., Raffaelli, D., Solan, M., and Srivastava, D.: Consequences of species loss for the ecosystem functioning: meta-analyses of data from biodiversity experiments, in: Biodiversity, Ecosystem Functioning, and Human Wellbeing: An Ecological and Economic Perspective, edited by: Naeem, S., Bunker, D. E., Hector, A., Loreau, M., and Perrings, C., Oxford University Press, Oxford, UK, 14-29, 2009.

Schulz, H. D.: Quantification of Early Diagenesis: Dissolved Constituents in Pore Water and Signals in the Solid Phase, in: Marine Geochemistry, edited by: Schulz, H. D. and Zabel, M., Springer Berlin Heidelberg, 73-124, 2006.

Simpson, K. G., Tremblay, J. E., Gratton, Y., and Price, N. M.: An annual study of inorganic and organic nitrogen and phosphorus and silicic acid in the southeastern Beaufort Sea, J. Geophys. Res.-Oceans, 113, C07016 doi:10.1029/2007jc004462, 2008.

Sun, M. Y., Carroll, M. L., Ambrose, W. G., Clough, L. M., Zou, L., and Lopez, G. R.: Rapid consumption of phytoplankton and ice algae by Arctic soft-sediment benthic communities: Evidence using natural and C-13-labeled food materials, J. Mar. Res., 65, 561-588, 2007.

Sun, M. Y., Clough, L. M., Carroll, M. L., Dai, J. H., Ambrose, W. G., and Lopez, G. R.: Different responses of two common Arctic macrobenthic species (Macoma balthica and Monoporeia affinis) to phytoplankton and ice algae: Will climate change impacts be species specific?, J. Exp. Mar. Biol. Ecol., 376, 110-121, 
doi:10.1016/j.jembe.2009.06.018, 2009.

Tolosa, I., Fiorini, S., Gasser, B., Martín, J., and Miquel, J. C.: Carbon sources in suspended particles and surface sediments from the Beaufort Sea revealed by molecular lipid biomarkers and compound-specific isotope analysis, Biogeosciences, 10, 2061-2087, doi:10.5194/bg-10-2061-2013, 2013.

Tréguer, P., Nelson, D. M., van Bennekom, A. J., DeMaster, D. J., Leynaert, A., and Queguiner, B.: The balance of silica in the world ocean: a re-estimate, Science, 268, 375-379, 1995.

Tremblay, J.-É., Bélanger, S., Barber, D., Asplin, M., Martin, J., Darnis, G., Fortier, L., Link, H., Gratton, Y., Archambault, P., Sallon, A., Michel, C., Williams, W., Gosselin, M., and Philippe, B.: Climate forcing multiplies biological productivity in the coastal Arctic Ocean, Geophys. Res. Lett., 38, L18604, doi:10.1029/2011GL048825, 2011.
Tribovillard, N., Algeo, T., and Lyons, T.:Trace metals as paleoredox and paleoproductivity proxies: An update, Chem. Geol., 232, 12-32, 2006.

Wassmann, P., Duarte, C. M., Agusti, S., and Sejr, M. K.: Footprints of climate change in the Arctic marine ecosystem, Glob. Change Biol., 17, 1235-1249, doi:10.1111/j.1365-2486.2010.02311.x, 2011.

Wenzhöfer, F. and Glud, R. N.: Benthic carbon mineralization in the Atlantic: a synthesis based on in situ data from the last decade, Deep-Sea Res. Pt. I, 49, 1255-1279, 2002.

Zabel, M. and Hensen, C.: Quantification and Regionalization of Benthic Reflux, in: Marine Geochemistry, edited by: Schulz, H. D. and Zabel, M., Springer Berlin Heidelberg, 429-456, 2006. 